\title{
Strategic Corporate Social Responsibility Orientation: From Gathering Information to Reporting Initiatives
}

\section{Dolores Gallardo-Vázquez ${ }^{a}$, Luis Enrique Valdez Juárez ${ }^{\mathrm{b}}$ \\ a) Department of Financial Economy and Accounting, Faculty of Economics and Business, University of Extremadura, Badajoz, SPAIN. b) Faculty of Economics and Business, Technological Institute of Sonora, Sonora, MEXICO.}

\author{
${ }^{a}$ Corresponding author.
}

E-mail address: dgallard@unex.es

\section{A R T I C L E I N F O}

\section{Article history:}

Received 11 December 2019

Accepted 14 July 2020

Available online 1 January 2022

\section{JEL classification:}

M14

M41

\section{Keywords:}

Corporate social responsibility

Information

Diffusion

Market orientation

Partial least squares (PLS)

\begin{abstract}
A B S T R A C T
Corporate social responsibility (CSR) strategies have become an important research topic in recent years as they can generate numerous benefits for organizations, especially when an adequate market orientation (MO) has been defined. In this sense, several research questions arise: do companies have enough CSR information to implement appropriate strategies? Does the information that they have gathered allow them to define a complete set of CSR activities (response) based on the triple bottom line approach? And, once they have carried out their initiatives, do these companies ensure adequate dissemination of the results to stakeholders?. In order to answer the above questions, this study sought to examine companies' CSR orientation from a MO perspective. Working with data on a sample of 165 firms in Spain, during January 15th and February 15th, 2017, structural equation modeling was used to test a set of research hypotheses. The results reveal an important link between information, response, and diffusion and help extend the MO strategy concept. CSR information has a positive, direct influence on the development of initiatives covering three dimensions (economic, social and environmental). In addition, a direct relationship exists between the development of social and environmental initiatives and CSR disclosure. This research's findings contribute to the literature on interest groups and business sustainability. Also, they confirm that the development of social and environmental initiatives contributes positively to CSR dissemination and to the generation of competitive advantages. This way, collecting CSR information constitutes a valuable asset. With respect to the limitations of the study, the answers reflected each SME leader's subjective opinion, the variables' measurement was dealt with through reflective models using the PLS technique based on variance and only Spanish companies already oriented toward CSR participated in the study.
\end{abstract}

(C)2022 ASEPUC. Published by EDITUM - Universidad de Murcia. This is an open access article under the CC BY-NC-ND license (http://creativecommons.org/licenses/by-nc-nd/4.0/).

Orientación estratégica de la Responsabilidad Social Corporativa: de la recopilación de información a la difusión de las actuaciones

R E S U M E N

Las estrategias de responsabilidad social corporativa (RSC) se han convertido en un tema de investigación importante en los últimos años, ya que pueden generar numerosos beneficios para las organizaciones, especialmente cuando se ha definido una orientación adecuada al mercado (OM). En este sentido, nos surgen varias preguntas de investigación: Edisponen las empresas de suficiente información de RSC para implementar adecuadas estrategias? fla información que poseen les permite definir un conjunto de actividades de RSC (respuesta) basadas en el enfoque del triple bottom line? Y, una vez que han llevado a cabo sus iniciativas, £estas empresas aseguran una adecuada difusión de los resultados a los grupos de interés?. Con el fin de dar respuesta a las anteriores cuestiones, este estudio buscó examinar la orientación de la RSC de las empresas desde una perspectiva OM. Trabajando con datos de una muestra de 165 empresas en España, durante el período comprendido desde el 15 de enero al 15 de febrero de 2017, se utilizaron los modelos de ecuaciones estructurales para probar un conjunto de hipótesis de investigación. Los resultados revelan un vínculo importante entre la información, la respuesta y la difusión y ayudan a extender el concepto de estrategia de OM. La información de RSC tiene una influencia positiva y directa en el desarrollo de iniciativas que cubren las tres dimensiones (económica, social y medioambiental). Además, existe una relación directa entre el desarrollo de iniciativas sociales y ambientales y la divulgación de la RSC. Los hallazgos de esta investigación contribuyen a la literatura sobre grupos de interés y sostenibilidad empresarial. Además, confirman que el desarrollo de iniciativas sociales y ambientales contribuye positivamente a la difusión de la RSE y a la generación de ventajas competitivas. De esta manera, la recogida de información de RSE constituye un activo valioso. Con respecto a las limitaciones del estudio, las respuestas reflejaron la opinión subjetiva de cada líder de las Pymes, la medición de las variables se trató a través de modelos reflectivos utilizando la técnica PLS basada en la varianza y solo las empresas españolas ya orientadas hacia la RSE participaron en el estudio.

(C2022 ASEPUC. Publicado por EDITUM - Universidad de Murcia. Este es un artículo Open Access bajo la licencia CC BY-NC-ND (http://creativecommons.org/licenses/by-nc-nd/4.0/). 


\section{Introduction}

Corporate social responsibility (CSR) has become an important research topic in recent decades (Gallardo-Vázquez \& Sánchez-Hernández, 2014a, 2014b; Valdez-Juárez, GallardoVázquez, \& Ramos-Escobar, 2018). CSR is clearly a strategy of imperative interest to all organizations, especially to large and small firms (Blanc, Branco, \& Patten, 2019; MartínezMartínez, Herrera, Larrán, \& Lechuga, 2017; MonevaAbadía, Gallardo-Vázquez, \& Sánchez-Hernández, 2018). An extensive literature already exists that discusses the benefits companies can receive from carrying out socially responsible initiatives. In CSR's internal sphere, CSR promotes social consciousness in corporate culture, increasing employees' involvement and commitment to their organization (e.g., Hao, Farooq, \& Zhang, 2018; Jones, 2010; Turker, 2009a, $2009 b)$. The literature also contains frequent mentions of reputation as a valuable, all-embracing resource strongly linked to socially responsible activities (Baldarelli \& Gigli, 2014; Jo, Kim, \& Park, 2015). In addition, CSR increases productivity, sales, and profits. Organizations' CSR practices facilitate the achievement of better performance and financial results, thereby positively affecting productivity, competitiveness, and competitive success (Boulouta \& Pitelis, 2014; Gallardo-Vázquez \& Sánchez-Hernández, 2014a; Rodrigo, Durán, \& Arenas, 2016). More recently, Hameed et al. (2016) have asserted that CSR initiatives can generate increased performance and value.

Thus, CSR is associated in the literature with numerous variables such as commitment, culture, image, reputation, competitive success, productivity, and performance. At the same time, the literature indicates that companies have little information, that is, they have little knowledge about what CSR is and how to put it into practice. Likewise, the disclosure of CSR carried out by companies is not very abundant. Therefore, it seems that the literature has delved into the actions carried out by companies, but not in the information possessed and in the disclosure made. So, a necessary starting point is to determine the level of CSR information that companies possess before they implement CSR strategies in the three dimensions (economic, social and environmental), because having some information about CSR makes companies to be engaged in CSR, and once they are involved, the next step is to communicate it. A gap was observed in the literature regarding the information possessed and the level of CSR diffusion. All these aspects are key in a market orientation (MO) strategy, which as we know consists of three steps: information, diffusion and response. Therefore, since the response is more elaborated in the previous literature, we wanted to delve into the less worked steps, information and diffusion. This underresearched topic was selected as the present research's focus. The present study, therefore, sought to answer the following research questions (RQ):

- RQ1: Do companies have enough CSR information to implement appropriate strategies?

- RQ2: Does the information that they have gathered allow them to define a complete set of activities based on the triple dimension approach?

- RQ3: Once they have carried out initiatives, do these companies ensure adequate dissemination of the results to stakeholders?

To address these questions, this study aimed, first, to achieve a better understanding of the relationships between
CSR information's effects and the development of CSR initiatives in three dimensions (i.e., economic, social, and environmental). This objective addressed the first two RQs raised (i.e., RQ1 and RQ2). Second, the research included analyzing the link between these initiatives' development and their diffusion, thus focusing on the third research question (i.e., RQ3). This study relied on structural equation models (SEMs) and applied the PLS technique to analyze data on a sample of 165 Spanish companies headquartered in the Autonomous Community of Extremadura.

The results extend the existing knowledge-from a sustainability perspective-about the MO concept developed by Kholi \& Jaworski (1990) and Narver \& Slater (1990). Although previous research (Bello, Halim, \& Alshuabi, 2018; Gallardo-Vázquez \& Sánchez-Hernández, 2014b; Kiessling, Isaksson, \& Yasar, 2016; Sánchez-Hernández, Carvalho, \& Paiva, 2019) has linked MO with CSR, the present study went beyond the existing investigations to examine the relationship between information possession and dissemination, which are both dependent on the development of socially responsible initiatives in the triple dimension. In order to highlight the contribution of this paper with respect to the previous literature, we note that the defined conceptual model is broader, incorporating in the response, the three dimensions of CSR, economic, social and environmental, going beyond the study of Gallardo-Vázquez \& Sánchez-Hernández (2014b). Also, this paper has focused on the dynamic capabilities and stakeholders theories, which are an extension of the theoretical approach used in Gallardo-Vázquez \& SánchezHernándezt's study (2014b), and making a very up-to-date presentation of MO and its extension towards CSR and therefore going much further than previous authors. Moreover, in this paper, the market concept has been extended to include multiple interest groups (e.g., customers, shareholders, managers, and employers) (Gallardo-Vázquez \& SánchezHernández, 2014b; Sánchez-Hernández et al., 2019). Also, the authors have presented a broader conceptual model, incorporating in the response, the three dimensions of CSR, economic, social and environmental, going beyond the study of Gallardo-Vázquez \& Sánchez-Hernández (2014b).

The findings can be considered a significant contribution to the literature because they can help managers control the information they generate during their firms' implementation of CSR practices and determine the level of dissemination needed. We consider that the focus of this work under the $\mathrm{MO}$ is adequate since it analyzes in depth the three components of said orientation (information, response or actuation, and dissemination or diffusion (Kholi \& Jaworski, 1990) under the CSR perspective. The results indicate the validity of the approach and the contribution of the study.

With respect to the novelty of the study, we have to say that given the current emphasis on sustainability, researchers have sought to define possible relationships between MO and socially responsible practices contributing to the achievement of sustainable performance. Prior literature have found a link between CSR and marketing, stating that MO significantly improves performance (Oduro \& Haylemariam, 2019). At the same time, CSR improves stakeholderst's perceptions (Barone, Norman, \& Miyazaki, 2007). Last contributions link $\mathrm{MO}$ and CSR from marketing perspective and performance, but we would like to extend to the CSR information and diffusion constructs. This way, we consider that this study is new and interesting relative to the prior literature. At the same time, this paper adds new empirical evidence to the study of stakeholders and dynamic capabilities theories.

The selected research topic's importance and the advant- 
ages of CSR can bring to organizations have motivated ongoing investigation over the years, leading to the incorporation of new visions and perspectives into the existing literature. The present study's results contribute to the literature on CSR strategies establishing how the fact of having CSR information will determine the development of initiatives in the triple bottom line approach. More specifically, the findings focus on Spanish companies that show an orientation toward CSR, which is a current topic in this field. Also, they confirm that the development of social and environmental initiatives contributes positively to CSR dissemination and to the generation of competitive advantages. This way, collecting CSR information constitutes a valuable asset.

This paper is organized as follows. The next section presents the theoretical background focused on MO and its extension through CSR. The hypotheses are then defined, as well as how they were used to develop the proposed conceptual model. The methods are subsequently described including the sample and data, variables, and measurement scales. The results are detailed, and, finally, the discussion, conclusions, and limitations are presented, together with possible lines of future research.

\section{Theoretical background and hypotheses' rationale}

\subsection{Stakeholder and dynamic capabilities theories}

The current globalized market has changed businesses' perspective from a focus on maximizing owners and/or shareholders' value (Martínez-Ferrero, 2014) to a vision that combines simultaneously complex and varied interactions between multiple stakeholders (Kiessling et al., 2016). This new perspective concentrates on the individuals or groups that benefit from or that are harmed by corporate actions (Freeman, 1998) and that contribute to the creation and distribution of economic value (Asher, Mahoney, \& Mahoney, 2005). These groups need to be considered in managementlevel decision making (Freeman, 1999), including, among others, owners, employees, customers, suppliers, local communities, and governments. This set of relationships is formalized in contracts defining rights, objectives, expectations, and responsibilities and thereby configuring organizations' current operational models (Fassin, de Colle, \& Freeman, 2016; Walsh, 2005) so that their success depends on properly managing these relationships (Freeman \& Philips, 2002).

Although the stakeholder theory has sometimes been criticized for having a weak empirical base and explanatory power (Frynas \& Yamahaki, 2016), this theory has been incorporated into many studies on CSR. The latter business strategy has gained interest and topicality in response to increased pressure from interest groups (Martínez-Martínez et al., 2017; Öberseder, Schlegelmilch, \& Gruber, 2011). In this context, experts need to take into account the importance of developing a comprehensive discourse with stakeholders and incorporating their responses into globalization scenarios (Richter \& Dow, 2017). Very recently, Vaitoonkiat and Charoensukmongkol (2020) investigate stakeholder orientationt's influence on firmt's performance from a MO perspective.

Dynamic capabilities theory has its roots in resource-based theory, with this new approach seeking to take companies to a higher level of responsibility with a dual-benefit approach (i.e., company-society). In addition, this theory includes the detection and exploitation of opportunities in potential markets, helping organizations' execute and apply internal and external resources to achieve sustainable results (Kachouie,
Mavondo, \& Sands, 2018; Teece, 2007). Strategic capabilities include MO and CSR, which have become pillars sustaining most organizations' growth and competitivenesswhether they are small or large-over the last two decades (Ledesma-Chaves, Arenas-Gaitan, \& García-Cruz, 2020; Teece, 2018).

A key dynamic capability for small and medium-sized enterprises (SMEs) is the process of generating knowledge, which facilitates the execution of strategic plans (Sarkar, Coelho, \& Maroco, 2016). Resources and knowledge, such as information, stimulate dynamic capabilities development (Bitencourt, Santini, Ladeira, Santos, \& Teixeira, 2020). A crucial CSR practice is the dissemination of information about the CSR activities companies develop. Therefore, CSR plans not only obtain internal and external information about company practices in social and environmental initiatives but also detect social problems related to the companies in question (Dentoni, Bitzer, \& Pascucci, 2016; Zbuchea \& Pînzaru, 2017). These initiatives contribute to generating more accurate reports on responsible firms' effects on their stakeholders (Galbreath, 2009; Ramachandran, 2011). However, many organizations have various internal limitations on their ability to develop CSR plans (Galbreath, 2009). After the two abovementioned theories' contributions were weighed, MO's fundamental principles were examined, including how they extend into CSR practices, as discussed in the next subsection.

\subsection{Market Orientation (MO)}

Performance improvement is clearly an objective that all organizations seek to achieve, but the strategies implemented to achieve it have been extremely varied. In marketing (Jogaratnam, 2017; Kajalo \& Lindblom, 2015), MO has been extensively studied, and this strategy has been extended to other organizational areas, reflecting the interdisciplinary approach that currently prevails. Kajalo \& Lindblom (2015) and Zehir, Köle, \& Yldz (2015) point out that MO improves organizational performance and generates competitive advantages. Other authors have also found evidence of a significant positive link between MO and performance (Bhatia \& Jain, 2015; Protcko \& Dornberger, 2014). Wang, Zhang, \& Song (2020) study the environmental conditions under which a MO strategy is more advantageous for firmt's performance. More specifically, researchers have reported a link between MO and profitability (Raju, Lonial, \& Crum, 2011; Smirnova, Naudé, Henneberg, Mouzas, \& Kouchtch, 2011) and MO and net sales and operating profit (Vega-Rodríguez \& Rojas-Berrio, 2011).

MO is a business philosophy with a specific perspective on how organizations adapt to their customer environment in order to achieve competitive advantages (Kohli \& Jaworski, 1990; Liao, Chang, Wu, \& Katrichis, 2011; Slater \& Narver, 2000). Kholi and Jaworski (1990, p. 6) define MO as "the organization wide generation of market intelligence pertaining to current and future customer needs, dissemination of the intelligence across departments, and organization wide responsiveness to it." The cited authors based their conceptualization of MO on three subconstructs. The first is the generation of market intelligence, which includes an analysis of customers' needs and preferences. The second is this intelligence's dissemination or disclosure within firms, which is an important step because the information constitutes a shared company value. The last subconstruct is firms' responsiveness to this market intelligence. In this context, companies obtain information on customers' present and future needs, act on that knowledge, and offer better services (Slater \& 
Narver, 2000). Efficient and effective services delivered to interested parties contribute to the satisfaction of changing market needs (Lechuga-Sancho, Martínez-Martínez, Larrán, \& Herrera, 2018).

Narver \& Slater (1990) further distinguished between three dimensions in MO: customer orientation, competitor orientation, and inter-functional coordination. Customer orientation focuses on knowing clients' needs, which allows companies to meet these needs and provide customers with superior value. This orientation places clients at the center of organizations' activities, helping firms achieve greater profitability and customer retention (Brady \& Cronin Jr., 2001).

Competitor orientation implies that companies can analyze and understand their rivals by paying greater attention to their activities before making decisions (Narver \& Slater, 1990). This approach focuses on creating differentiation in the market (Grinstein, 2008; Im \& Workman Jr., 2004) and obtaining competitive advantages and sustainable performance. Finally, inter-functional coordination implies communication practices that can help firms improve their services (Grinstein, 2008). Offering better services to customers, identifying competitors' strategies, and coordinating communication and interactions are signs of an adequate MO capable of generating benefits and achieving advantages over the competition (Narver \& Slater, 1990).

Given the current emphasis on sustainability, researchers have sought to define possible relationships between MO and socially responsible practices contributing to the achievement of sustainable performance. Oduro and Haylemariam's (2019) work found a link between CSR and marketing in manufacturing companies in Ghana and Ethiopia. The cited authors' findings include that MO significantly improves performance, with different effects depending on the country in question and the level of CSR implemented. Concurrently, CSR generates more humanistic market-oriented activities (Barone, Norman, \& Miyazaki, 2007; Du, Bhattacharya, \& Sen, 2007), thereby improving stakeholders' perceptions. Jiang, Rosati, Chai, \& Fengt's paper (2020) applies the OM perspective in its connection with the creation of knowledge and environmental performance in Chinese companies. The authors conclude that the creation of knowledge (information in our case) mediates the influence of customer orientation on environmental performance. This highlights the importance of having information.

\subsection{Extension of $M O$ into $C S R$}

Pressures from various interest groups have motivated organizations to pay more attention to CSR strategies (Öberseder et al., 2011). Companies now need to apply a broader market approach to achieve their objectives (Kang, 2009; Luo \& Battacharya, 2009) due to better organized customers who have more information, which makes them more demanding and more interested in the implementation of socially responsible initiatives. CSR has thus become a vital strategy for companies (Bondy, Moon, \& Matten, 2012; Carroll \& Shabana, 2010), as well as a strategic marketing component of great importance to competitive success (Carroll \& Shabana, 2010; Kiessling et al., 2016; Luo \& Bhattacharya, 2009).

Luo and Bhattacharya (2009) suggest that the current prevalence of the MO perspective causes customers to prefer CSR-focused companies that, when they have the knowledge to do so, will implement CSR strategies. In short, the literature on MO and CSR suggests not only a direct effect on financial performance but also indirect-and sometimes difficult to quantify-impacts such as customer loyalty and stronger relationships with stakeholders (Du, Bhattacharya, \& Sen, 2010; Kirca, Jayachandran, \& Bearden, 2005). The present study used the MO perspective to gain a clearer, fuller understanding of firms' CSR strategies (Kholi \& Jaworski, 1990; Narver \& Slater, 1990).

Given the current interest in the link between MO and CSR, Gallardo-Vázquez \& Sánchez-Hernández (2014b) and Sánchez-Hernández et al. (2019) work relied on Kholi \& Jaworski (1990) and Narver \& Slater's (1990) conceptualization of MO to examine CSR more closely. More specifically, Gallardo-Vázquez \& Sánchez-Hernández (2014b) and Sánchez-Hernández et al. (2019) adapted marketing concepts and strategic approaches to explain CSR orientation models more fully, as have other authors (Bello et al., 2018; Kiessling et al., 2016). As noted previously, the original understanding of $\mathrm{MO}$ included satisfying customers' needs (Kholi \& Jaworski, 1990; Narver \& Slater, 1990). From this perspective, every organization must carry out initiatives that take into account the relevant stakeholders. To define the MO construct from a CSR perspective, the market concept has been extended (Gallardo-Vázquez \& Sánchez-Hernández, 2014b) to include multiple interest groups (e.g., customers, shareholders, managers, and employers).

As mentioned previously, Gallardo-Vázquez \& SánchezHernández (2014b) addressed MO from the CSR perspective by expanding the stakeholder orientation and affirming that MO is related to the use of CSR information. The cited authors defined a conceptual model of causal relationships between three variables-information, dissemination, and environmental response-to evaluate CSR-related MO. Kiessling et al. (2016) also used the MO framework as a theoretical foundation in their exploration of CSR. The cited researchers postulate that firms gather knowledge about their customers' needs because they are vital stakeholders, and this information allows companies to carry out new CSR activities and achieve competitive advantages.

Based on this theoretical framework, Bello et al. (2018) developed an analytical model of the direct relationships between MO dimensions and sustainability performance. Sánchez-Hernández et al. (2019) further defined a composite model of information, diffusion, and response for African firms. The cited authors argue that companies get CSR information from their markets and that firms coordinate their resources internally and offer responses to stakeholders' needs. Through this process, companies become marketoriented and co-create value through CSR strategies.

Thus, applying Kholi \& Jaworski's (1990) approach to MO provides organizations with a unifying approach that contributes to improved performance and other potential benefits. The present study's conceptualization of MO included this sustainable approach (Gallardo-Vázquez \& Sánchez-Hernández, 2014b; Kiessling et al., 2016; SánchezHernández et al., 2019). Within the CSR framework, MO can be contextualized in three dimensions: information, response or actuation, and dissemination or diffusion (Gallardo-Vázquez \& Sánchez-Hernández, 2014b; Kholi \& Jaworski, 1990). These formed the three pillars for the current research's conceptual model (see Figure 1).

In this approach, MO is supported by the application of stakeholder theory, which seeks to define how multiple interest groups can be satisfied. Concurrently, the proper management of resources based on an application of dynamic capabilities theory generates value creation with multiple benefits for organizations. After developing the above theoretical framework, the hypotheses that support the conceptual 
model were formulated.

\subsection{CSR information and CSR initiatives}

Information is without question an important asset necessary to manage according to the dynamic capabilities theory. The European Commission (EC) highlights information's importance to businesses in its report "European SMEs and Social and Environmental Responsibility" (EC, 2002). In addition, the study "CSR Communication: Talking to People Who Listen" published by APCO Worldwide (2004) also emphasizes the significance of CSR information to companies. Many authors have since focused on CSR information (Fisher, Geenen, Jurcevic, McClintock, \& Davis, 2009; Hammann, Habisch, \& Pechlaner, 2009; Nielsen \& Thomsen, 2009; Patenaude, 2011; Vidal, Bull, \& Kozak, 2010). According to Liu, Li, Quan, \& Yang (2019), information has become a crucial commodity able to detect opportunities in potential markets, as indicated by the theory mentioned above.

In addition, information is a necessary asset for companies seeking to develop CSR activities among the different interest groups and for the benefit of them, as indicated by the stakeholders theory. Without information, firms encounter difficulties in carrying out these initiatives. Gallardo-Vázquez \& Sánchez-Hernández (2014b) found evidence of a direct, positive relationship between the CSR information gathered by SMEs and their environmental initiatives. The cited authors were also able to corroborate a direct, positive relationship between CSR information and SMEs' disclosure of their environmental initiatives. Thus, having CSR information facilitates the carrying out of initiatives based on this strategy, achieving the satisfaction of all stakeholders.

However, Liu et al. (2019) report that the privatization of the cost of gathering CSR information has had a negative impact on the sustainable development of this information's supply chain. Nonetheless, according to Kholi \& Jaworski (1990), companies need to carry out initiatives or develop responses based on the triple bottom line approach (Jeurissen, 2000), which takes into consideration three dimensions: economic, social, and environmental, oriented to achieve an adequate application of resources as indicated by the dynamic capabilities theory.

More recent studies have found the CSR information possessed by innovative companies whose leadership engage in behaviors focused on sustainability-as defined by interest groups-has become a key factor in generating greater confidence and legitimacy. These strategies have also generated more economic benefits (Duff, 2017; Ghouri, Akhtar, Shahbaz, \& Shabbir, 2019). However, some SMEs (i.e., mostly family-owned) still do not have as much CSR information as large organizations, which prevents these SMEs from implementing CSR initiatives and puts these companies at a disadvantage (Cabeza-García, Sacristán-Navarro, \& GómezAnsón, 2017; Steinhöfel, Galeitzke, Kohl, \& Orth, 2019). Specific contexts have allowed different SMEs from regions with highly developed economies to collect CSR information that allows these firms to include CSR practices in their strategic plans from the generation of knowledge derived from that CSR information, as postulated by the aforementioned theory (Campos \& Grangel, 2019; Cea, 2019).

Recently, the digital transformation process has had a further positive effect, and companies that avoid stagnation and fight to be more innovative through their initiatives can gather more information in different ways and use it to help implement CSR initiatives, looking for a better application of resources (dynamic capabilities theory). More specifically, big data is of great value to companies that need to penetrate communities and groups of interest quickly, generating satisfaction for stakeholders and maximizing value for all (stakeholders theory) (Corazza, 2019; Sivarajah, Irani, Gupta, \& Mahroof, 2019). Based on the existing research, the present study proposed the following hypotheses:

H1: CSR information has a direct, positive influence on the development of social dimension initiatives.

H2: CSR information has a direct, positive influence on the development of economic dimension initiatives.

H3: CSR information has a direct, positive influence on the development of environmental dimension initiatives.

As we can deduce, this first three hypotheses lead to achieve a better understanding of the relationships between CSR information's effects and the development of CSR initiatives in three dimensions (i.e., economic, social, and environmental). This way, the first two RQs raised (i.e., RQ1 and RQ2) are addressed. That is to say, companies that have enough CSR information to implement strategies will be able to define a set of actions based on the triple dimension approach.

\subsection{CSR initiatives and CSR disclosure}

Companies disseminate information about their social, economic, and environmental impacts inside and outside of their organization, namely, as CSR disclosure (Brunton, Eweje, \& Taskin, 2017; Thijssens, Bollen, \& Hassink, 2015), which has been extensively researched. The CSR disclosure process is voluntary, and it is based on the guidelines of existing standards (Bhaduri \& Selarka, 2016) and supported by the Global Reporting Initiative. ${ }^{1}$ These standards help companies to implement and manage information about their CSR practices, thereby offering responses to their stakeholders' questions about firms' impacts on society and allowing companies to provide proof of their legitimacy, seeking the satisfaction of all stakeholders, as indicated by the stakeholders theory (Brunsson, Rasche, \& Seidl, 2012; Vigneau, Humphreys, \& Moon, 2015). The dissemination of CSR practices is carried out via sustainability reports.

Companies' reporting strategy is determined by numerous factors, such as their sector, market, firm size, and corporate ownership (e.g., Reverte, 2009; Thanasanborrisude \& Phadoongsitthi, 2015). The existing literature further reports that CSR disclosure is directly and positively related to profitability (Gamerschlag, Möller, \& Verbeeten, 2011). Siueia, Wang, \& Deladem (2019) found a significant positive relationship between financial performance and CSR disclosure, suggesting that CSR behaviors help improve banks' performance. Kouloukoui et al. (2019) also contend that corporate disclosure has a significant positive relationship with firm size, financial performance, and country of origin. However, CSR disclosure has a negative association with level of indebtedness.

Recent studies have shown that disclosure currently is not transparent enough and that it provides inadequate information about companies' CSR practices, which weakens these firms' image and reputation (Gangi, Meles, Monferrà, \& Mustilli, 2018; Johnstone, 2019). In general, strategic decisions about disclosure are made by shareholders because

\footnotetext{
${ }^{1}$ More information is available at https://www.globalreporting.org/ Pages/default.aspx.
} 
most SMEs rely on a more robust business model of CSR initiatives. This approach motivates organizations to gather and disseminate information on CSR's social, economic, and environmental impacts on stakeholders, applying resources on the one hand (dynamic capabilities theory) and generating satisfaction on the other (stakeholder theory) (RamónLlorens, García-Meca, \& Pucheta-Martínez, 2018; Tsalis, Stylianou, \& Nikolaou, 2018).

Although more developed countries have regulations that mandate the full, transparent dissemination of CSR results through reports, many SMEs have not yet complied with these laws (Andrades \& Larrán, 2019; Andrades, MartínezMartínez, Larrán, \& Herrera, 2019). In addition, in times of crisis and economic recession, companies tend to focus on promoting internal CSR initiatives and solidifying their corporate governance while neglecting social initiatives. These firms give little importance to employee assets and invest few of their financial resources in environmental initiatives, which results in a loss of interest in reporting and disseminating CSR results (Larrán, Andrades, \& Herrera, 2019; Sakunasingha, Jiraporn, \& Uyar, 2018).

The present study thus proposed these hypotheses:

H4: A direct, positive relationship exists between the development of social dimension initiatives and CSR diffusion.

H5: A direct, positive relationship exists between the development of economic dimension initiatives and CSR diffusion.

H6: A direct, positive relationship exists between the development of environmental dimension initiatives and CSR diffusion.

This three hypothesis lead to analyze the link between these initiatives' development and their diffusion, thus focusing on the third research question (i.e., RQ3). In this sense, once companies have carried out their initiatives, they should ensure adequate dissemination of the results.

Figure 1 presents the hypothesized relationships tested in this research.

Figure 1. Conceptual model and hypotheses

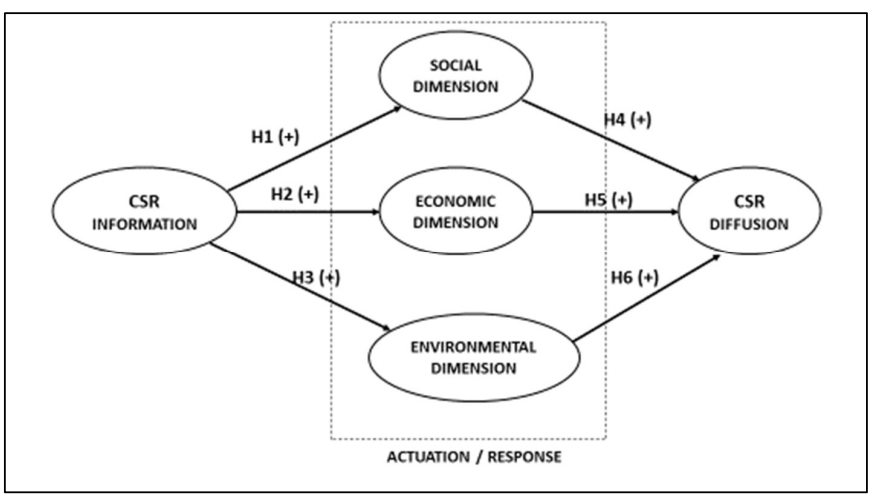

Source: Authors

\section{Methods}

\subsection{SEMs}

SEMs were used to test the conceptual model proposed. To this end, the partial least squares (PLS) statistical technique was applied with the help of SmartPLS 3.2.8 Professional
Full Version software (Ringle, Wende, \& Becker, 2014). The present study's models were based on an econometric perspective oriented toward prediction and focused on latent or unobserved variables, which were inferred from indicators (Chin, 1998b). These models are considered second generation multivariate models that allow, first, the incorporation of abstract constructs not directly observable. Second, the models facilitate the determination of the degree to which measurable variables describe latent variables, and, third, SEMs incorporate relationships between multiple predictor variables and criteria. Last, the models combine and test hypotheses emanating from previous theoretical knowledge based on data collected empirically (Chin, 1998a).

Numerous investigations have used this technique in the social sciences and, more specifically, addressed the study of CSR in SMEs, as the current research did. Of particular note are the studies by Gallardo-Vázquez \& Sánchez-Hernández (2014a); Gallardo-Vázquez et al. (2013); Herrera-Madueño et al. (2016); López-Pérez, Melero, \& Sese (2017), and Valdez-Juárez (2017). In addition, SEM methodology has been applied to the relationships between CSR and other variables in SME contexts, such as performance (HerreraMadueño et al., 2016, Reverte, Gómez-Melero, \& CegarraNavarro, 2016), competitiveness (Marín, Rubio, \& Ruiz, 2012, Yu, Kuo, \& Kao, 2017), and innovation (MartínezConesa, Soto-Acosta, \& Palacios-Manzano, 2017; Rexhepi, Kurtishi, \& Bexheti, 2013). The extensive application of the PLS technique gives these studies' empirical foundations more credibility, guaranteeing researchers have obtained optimal results. This body of literature thus supports the validity of the present study's approach and contribution to the existing knowledge in this field.

\subsection{Sample and data}

This study focused on companies in the first Spanish region (i.e., Extremadura) to approve an act promoting CSR practices (i.e., Law 15/2010 of December 9 on Corporate Social Responsibility in Extremadura). This region thus offers specific conditions regarding CSR, and Extremadura companies can formulate distinctive responses. The law defines a constructive, nonpunitive framework that gives value to these firms' efforts to follow socially responsible strategies. In addition, at the regional, national, and international level, the government uses laws to provide companies with opportunities, allowing these firms to take on responsible roles in the market and to become examples for other companies by monitoring their own behaviors.

The data were collected with a structured Google questionnaire distributed via email to companiest' managers. The companies chosen to be part of the sample were selected taking into account that they were previously sensitized to CSR, even though they had a weak CSR strategy. This method was selected for two reasons. First, the database's definition was conditioned because messages could only be sent to those firms that have published their address in the relevant networks and thus have greater visibility. Second, the sample could only include those companies that chose to fill out the survey.

The questionnaire was delivered between January 15th and February 15th, 2017. Emails were sent to 1,882 companies. A total of 165 questionnaires were completed, yielding a response rate of $11.41 \%$ (see Table 1 ). The questionnaires were sent to managers of companies sensitized to CSR issues, who showed great interest in sharing their perceptions on the topic under study. However, the answer does not always 
come from managers. Thus, although at first it was directed to presidents, general directors or other directors, later this possibility was opened, giving the option to have it answered by personnel who, without holding the aforementioned positions, but did know the CSR actions carried out by the company. The questionnaire was sent and collected via e-mail, with a maximum of five reminder emails sent to each company if no previous response was obtained. The answers to the initial email covered a variety of responses ranging from "thank you for including us" to "I am not interested in participating" or "my time is money, so I do nothing for free."

Table 1. Study technical sheet

\begin{tabular}{ll}
\hline \multicolumn{2}{c}{ Data sheet of sample information } \\
\hline Universe of study & $\begin{array}{l}\text { Extremadura companies: } \\
\text { companies of all sizes } \dagger\end{array}$ \\
$\begin{array}{l}\text { Geographical scope } \\
\text { Method of gathering information } \\
\text { Number of companies to which } \\
\text { Structured Google questionnaire sent } \\
\text { by email } \\
\text { emails were sent }\end{array}$ & 1,882 \\
Sample & 165 \\
Response collection period & Between January $15^{\text {th }}$ and February \\
& $15^{\text {th }}, 2017$ \\
Participation rate & $11.41 \%$ \\
Sample error & $7.3 \%$ \\
Confidence level & $95 \%$ \\
\hline Note: $\dagger$ Source: Directorio Central de Empresas (2016) \\
Source: Authors
\end{tabular}

Among the companies that did not answer the questionnaire, the reasons included 11 companies who indicated that they could not fill in the questionnaire because they did not have a Google account. A further 6 companies reported that for various reasons they could not access the questionnaire, while 4 companies replied that they were not interested in participating and 2 companies requested more information before completing the questionnaire. Two other companies indicated that they were in bankruptcy proceedings and that they did not have the personnel needed to answer the questionnaire. One company said it had been closed down, and another company said it would not participate in the survey because no one had any idea what corporate responsibility meant. The two companies that requested further information ended up answering the questionnaire. Therefore, of the 1,717 companies that did not participate, 25 provided the reason why they did not participate, which left 1,692 companies that did not participate or acknowledge being contacted for unknown reasons.

A preliminary analysis revealed that $73.33 \%$ of the companies surveyed belong to the tertiary or services sector, $18.18 \%$ to the secondary sector, and $8.48 \%$ to the primary sector. Within the primary sector companies, $64.29 \%$ are engaged in agricultural livestock activities and $35.71 \%$ in extractive activities. Of the secondary sector firms, $46.7 \%$ belong to the food industry, while $23.3 \%$ are involved in metalworking, $20 \%$ in other manufacturing activities, and $10 \%$ in wood, cork, paper, and furniture production. Regarding the tertiary sector companies, $33.1 \%$ offer other services, $26.4 \%$ are in commerce and $17.4 \%$ in construction.

In terms of company size, most firms surveyed had between 10 and 49 employees (53.33\%), followed by companies with less than 10 employees (38.79\%). The remaining $8 \%$ was businesses with between 50 and 249 workers $(6.06 \%)$ and companies with more than 250 workers $(1.82 \%)$. With regard to the respondents' position within their company, the majority were presidents and/or general managers (36.4\%), followed by those in administrative positions $(27.9 \%)$. The respondents who checked "Other" (16.4\%) and thus were not administrators reported having a variety of positions. These included, among others, communication director; human resources (HR) manager; quality manager; research, development, and innovation manager; marketing technician; purchasing manager; and accountant.

\subsection{Measurement scales}

CSR information and CSR diffusion. The scales focused on these two constructs were based on Gallardo-Vázquez and Sánchez-Hernández's (2014b) work. CSR information was measured using 4 items and CSR diffusion with 5 items. More recently, these scales have also been used by SánchezHernández et al. (2019).

CSR's social, economic, and environmental dimensions. The scales concentrating on these three CSR dimensions were based on Gallardo-Vázquez and Sánchez-Hernández's (2014a) research. The social dimension was measured using 15 items, the economic dimension with 11 items, and the environmental dimension with 9 items. Subsequently, these scales were used in Moneva-Abadía et al. (2018) study.

Responses to all items used a 5-point Likert-type scale (1 $=$ "Strongly disagree"; $5=$ "Strongly agree"). The questionnaire with all items is provided in Appendix 1, and those items that were validated in the model are marked with a superscript letter a.

\section{Data analysis and results}

\subsection{Descriptive statistics}

Table 2 shows the mean and standard deviation of all the items used to measure the model's constructs. Regarding Extremadura companies' CSR information, the results reveal that this is limited, which indicates the firms surveyed need to adopt new information acquisition mechanisms. The respondents gave these items mean values of 3.121, 3.000, 3.679 , and 3.061 on a scale of 0 to 5 . With regard to CSR's social dimension, in general, the values are higher, ranging from 2.794 to 4.309 . In this case, companies' managers should work on strengthening their perception of the importance of having employee pension plans and encouraging employees to participate in volunteer activities or in collaboration projects with non-governmental organizations.

For CSR's economic dimension, mean values range from 3.879 to 4.594 , which indicates that managers understand the importance of implementing CSR initiatives and their financial repercussions within the company. Nonetheless, improvements need to be made to ensure effective procedures for handling complaints and more positive perceptions of firms' financial management as deserving regional or national public support. Regarding CSR's environmental dimension, the mean values are also good, ranging from 3.473 to 4.418. However, companies still have to give greater importance to their participation in activities related to the protection and enhancement of the natural environment and the use of consumables, goods-in-process, and/or processed goods with a low environmental impact.

Finally, with regard to CSR diffusion, the average values are again lower, ranging from 2.552 to 3.321 . These results indicate companies need to disseminate information on socially responsible initiatives using all the instruments available (e.g., sustainability reports, codes of conduct, internal reports, and websites). The firms also should become active 
Table 2. Mean and standard deviation

\begin{tabular}{|c|c|c|c|}
\hline Construct & Item & Mean & Standard deviation \\
\hline \multirow[t]{4}{*}{ CSR information } & I1 & 3.121 & 1.094 \\
\hline & $\mathrm{I} 2$ & 3.000 & 1.128 \\
\hline & I3 & 3.679 & 0.985 \\
\hline & I4 & 3.061 & 1.099 \\
\hline \multirow[t]{15}{*}{ Social dimension of CSR } & SD1 & 3.284 & 0.860 \\
\hline & SD2 & 4.188 & 0.767 \\
\hline & SD3 & 4.236 & 0.695 \\
\hline & SD4 & 3.636 & 0.888 \\
\hline & SD5 & 3.727 & 0.956 \\
\hline & SD6 & 3.848 & 0.806 \\
\hline & SD7 & 3.988 & 0.901 \\
\hline & SD8 & 4.145 & 0.780 \\
\hline & SD9 & 3.903 & 0.889 \\
\hline & SD10 & 3.970 & 0.870 \\
\hline & SD11 & 4.309 & 0.657 \\
\hline & SD12 & 3.321 & 0.991 \\
\hline & SD13 & 2.794 & 1.053 \\
\hline & SD14 & 4.042 & 0.812 \\
\hline & SD15 & 2.855 & 1.091 \\
\hline \multirow{11}{*}{$\begin{array}{l}\text { Economic dimension } \\
\text { of CSR }\end{array}$} & ED1 & 4.594 & 0.631 \\
\hline & ED2 & 4.533 & 0.638 \\
\hline & ED3 & 4.358 & 0.713 \\
\hline & ED4 & 4.042 & 0.841 \\
\hline & ED5 & 4.424 & 0.662 \\
\hline & ED6 & 4.218 & 0.731 \\
\hline & ED7 & 4.424 & 0.653 \\
\hline & ED8 & 4.315 & 0.745 \\
\hline & ED9 & 4.176 & 0.927 \\
\hline & ED10 & 3.879 & 1.002 \\
\hline & ED11 & 3.939 & 0.983 \\
\hline \multirow{9}{*}{$\begin{array}{l}\text { Environmental dimension } \\
\text { of CSR }\end{array}$} & $\mathrm{AD} 1$ & 3.909 & 0.800 \\
\hline & $\mathrm{AD} 2$ & 3.745 & 0.806 \\
\hline & AD3 & 4.188 & 0.701 \\
\hline & $\mathrm{AD} 4$ & 4.145 & 0.788 \\
\hline & $\mathrm{AD} 5$ & 3.473 & 1.006 \\
\hline & AD6 & 4.042 & 0.708 \\
\hline & AD7 & 4.418 & 0.614 \\
\hline & $\mathrm{AD} 8$ & 3.836 & 0.910 \\
\hline & AD9 & 3.867 & 0.950 \\
\hline \multirow[t]{5}{*}{ CSR diffusion } & D1 & 3.321 & 1.128 \\
\hline & D2 & 2.715 & 1.127 \\
\hline & D3 & 2.988 & 1.139 \\
\hline & D4 & 3.267 & 1.091 \\
\hline & D5 & 2.552 & 1.228 \\
\hline
\end{tabular}

Source: Authors

members of organizations, businesses, or professional association or discussion forums that promote the implementation of social responsibility.

\subsection{Inner model assessment}

To assess the measurement instrument's reliability, each item's individual reliability was calculated, as well as the scales' reliability and average variance extracted (AVE). When measuring items' $(\lambda)$ relationship and individual reliability, factor loadings need to be greater than 0.707 ( $\lambda$ $>$ 0.707) (e.g., Chin \& Dibbern, 2010; Roberts, Priest, \& Traynor, 2006). The values obtained in the present research range from 0.701 to 0.862 . Of the initial 48 items, a total of 27 indicators were retained for further analysis (see Table 3 ).

Next, the measurement model was evaluated by reviewing the instrument's overall reliability. Cronbach's alpha and
Table 3. Measurement model

\begin{tabular}{|c|c|c|c|c|c|}
\hline Construct & Indicator & $\begin{array}{c}\text { Factor } \\
\text { loading }(\lambda)\end{array}$ & $\begin{array}{c}\text { Cronbach's } \\
\text { alpha }\end{array}$ & $\begin{array}{l}\text { Composite } \\
\text { reliability }\end{array}$ & AVE \\
\hline \multirow{3}{*}{ CSR information } & I2 & 0.743 & 0.765 & 0.861 & 0.675 \\
\hline & I3 & 0.862 & & & \\
\hline & I4 & 0.854 & & & \\
\hline \multirow[t]{4}{*}{ CSR diffusion } & D1 & 0.818 & 0.780 & 0.856 & 0.599 \\
\hline & D2 & 0.708 & & & \\
\hline & D3 & 0.731 & & & \\
\hline & D4 & 0.832 & & & \\
\hline \multirow{5}{*}{$\begin{array}{l}\text { Social dimension } \\
\text { of CSR }\end{array}$} & SD3 & 0.795 & 0,846 & 0.891 & 0.620 \\
\hline & SD6 & 0.763 & & & \\
\hline & SD7 & 0.751 & & & \\
\hline & SD8 & 0.856 & & & \\
\hline & SD14 & 0.768 & & & \\
\hline \multirow{7}{*}{$\begin{array}{l}\text { Economic } \\
\text { dimension } \\
\text { of CSR }\end{array}$} & ED1 & 0.796 & 0.899 & 0.921 & 0.624 \\
\hline & ED2 & 0.800 & & & \\
\hline & ED5 & 0.834 & & & \\
\hline & ED6 & 0.774 & & & \\
\hline & ED7 & 0.826 & & & \\
\hline & ED8 & 0.780 & & & \\
\hline & ED10 & 0.716 & & & \\
\hline \multirow{9}{*}{$\begin{array}{l}\text { Environmental } \\
\text { dimension } \\
\text { of CSR }\end{array}$} & $\mathrm{AD} 1$ & 0.759 & 0.896 & 0.915 & 0.544 \\
\hline & $\mathrm{AD} 2$ & 0.772 & & & \\
\hline & AD3 & 0.764 & & & \\
\hline & $\mathrm{AD} 4$ & 0.725 & & & \\
\hline & AD5 & 0.701 & & & \\
\hline & AD6 & 0.735 & & & \\
\hline & AD7 & 0.722 & & & \\
\hline & AD8 & 0.755 & & & \\
\hline & AD9 & 0.701 & & & \\
\hline
\end{tabular}

Source: Authors

composite reliability were used since they indicate how well a set of items measures a latent variable. The Cronbach's alpha values in the current study were also considered satisfactory because they are over 0.70 (Hair, Black, Babin, Anderson, \& Tatham, 2006), falling between 0.765 and 0.899 . That is, a value of 0.765 was obtained for CSR information, 0.780 for CSR diffusion, 0.846 for CSR's social dimension, 0.896 for the environmental dimension, and 0.899 for the economic dimension. These results confirm the scales' high reliability (see Table 1 above).

The composite reliability analysis also produced acceptable values ranging from 0.856 to 0.921 . Namely, a value of 0.856 was obtained for CSR diffusion, 0.861 for CSR information, 0.891 for CSR's social dimension, 0.915 for the environmental dimension, and 0.921 for the economic dimension. Nunnally (1978) and Vandenberg \& Lance (2000) recommend scores above 0.80 for advanced research (see Table 3 above). Therefore, the constructs' internal consistency was confirmed.

To assess the model's validity, the constructs' convergent and discriminant validity were checked. Convergent validity shows the degree to which distinct approaches to construct measurement can lead to the same outcomes. This type of validity was analyzed by calculating the AVE (Fornell \& Larcker, 1981; Hair, Ringle, \& Sarstedt, 2011). The AVE values range from 0.544 to 0.675 . More specifically, a value of 0.544 was obtained for CSR's environmental dimension, 0.599 for CSR diffusion, 0.620 for CSR's social dimension, 0.624 for the economic dimension, and 0.675 for CSR information. These results are satisfactory because the values need to be higher than 0.500 (Hair, Black, Babin, Anderson, \& Tatham, 2010). Table 3 above shows that the conditions of the recommended minimum are met, so the model constructs' convergent validity can be considered satisfactory.

Finally, the constructs' discriminant validity reveals the existence of differences between each construct and its items 
with respect to the other constructs and their items. According to Fornell \& Larcker's (1981) criterion, this form of validity can be verified by analyzing the square root of AVE. The values-shown in diagonal and bold in Table 4-for vertical and horizontal AVE are below the correlations between constructs (Henseler, Ringle, \& Sarstedt, 2015; Roldán \& Sánchez-Franco, 2012) (i.e., $0.774>0.336$, 0.526, 0.486, and $0.756 ; 0.790>0.336,0.535,0.664$, and $0.324 ; 0.738>$ $0.526,0.535,0.607$, and $0.462 ; 0.787>0.486,0.664,0.607$, and $0.414 ; 0.822>0.756,0.324,0.462$, and 4.414). These results confirm the model's discriminant validity.

Table 4. Constructs' discriminant validity (Fornell and Larcker's criterion)

\begin{tabular}{|c|c|c|c|c|c|}
\hline Construct & $\begin{array}{c}\text { CSR } \\
\text { diffusion }\end{array}$ & $\begin{array}{l}\text { Economic } \\
\text { dimension }\end{array}$ & $\begin{array}{c}\text { Environmental } \\
\text { dimension }\end{array}$ & $\begin{array}{c}\text { Social } \\
\text { dimension }\end{array}$ & $\begin{array}{c}\text { CSR } \\
\text { information }\end{array}$ \\
\hline CSR diffusion & 0.774 & & & & \\
\hline $\begin{array}{l}\text { Economic } \\
\text { dimension }\end{array}$ & 0.336 & 0.790 & & & \\
\hline $\begin{array}{l}\text { Environmental } \\
\text { dimension }\end{array}$ & 0.526 & 0.535 & 0.738 & & \\
\hline Social dimension & 0.486 & 0.664 & 0.607 & 0.787 & \\
\hline CSR information & 0.756 & 0.324 & 0.462 & 0.414 & 0.822 \\
\hline
\end{tabular}

Source: Authors

Concurrently, discriminant validity was calculated based on the heterotrait-monotrait ratio (HTMT) (see Table 5). Henseler, Ringle, \& Sarstedt (2015) and Roldán and SánchezFranco (2012) indicate a maximum threshold of 0.90 is acceptable. The values in Table 4 above are all below that value. According to this criterion, all the model's variables also achieved discriminant validity. The results, therefore, confirm that all constructs in the present study meet the established discriminant validity criteria. The model's nomogram could be constructed next (see Figure 2).

Table 5. Construct discriminant validity (HTMT)

\begin{tabular}{|c|c|c|c|c|}
\hline Construct & $\begin{array}{c}\text { CSR } \\
\text { diffusion }\end{array}$ & $\begin{array}{l}\text { Economic } \\
\text { dimension }\end{array}$ & $\begin{array}{c}\text { Environmental } \\
\text { dimension }\end{array}$ & $\begin{array}{cc}\text { Social } & \text { CSR } \\
\text { dimension } & \text { information }\end{array}$ \\
\hline \multicolumn{5}{|l|}{ CSR diffusion } \\
\hline $\begin{array}{l}\text { Economic } \\
\text { dimension }\end{array}$ & 0.374 & & & \\
\hline $\begin{array}{l}\text { Environmental } \\
\text { dimension }\end{array}$ & 0.585 & 0.606 & & \\
\hline Social dimension & 0.568 & 0.756 & 0.701 & \\
\hline CSR information & 0.581 & 0.358 & 0.536 & 0.482 \\
\hline
\end{tabular}

Source: Authors

\subsection{Outer model assessment}

The structural model was used to evaluate the weight and magnitude of the relationships between the model's different variables taken from the research hypotheses (Wright, Campbell, Thatcher, \& Robert, 2012). Thus, the model's predictive power had to be assessed first. The predictor variables' contribution to the explained variance of the endogenous variables was evaluated by analyzing the path coefficients $(\beta)$ or standardized regression weights obtained. Chin (1998b) proposes that these weights need to present values exceeding 0.2

Figure 2. Explanatory nomogram

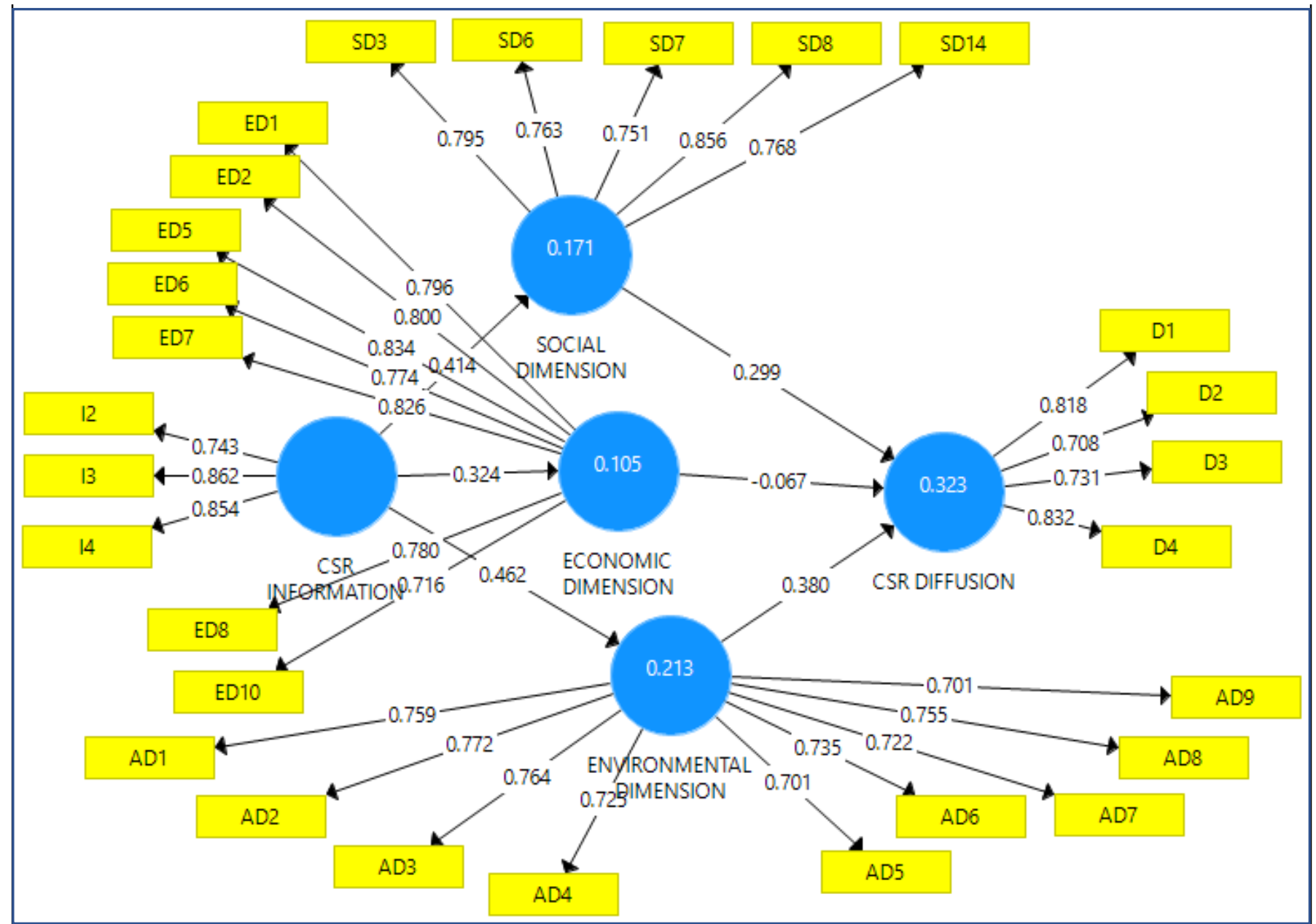

Source: Authors 
Table 6. Hypotheses contrasted (correlation and variance explained)

\begin{tabular}{|c|c|c|c|c|c|c|}
\hline Hypothesis & $\begin{array}{l}\text { Path coefficient } \\
(\beta)\end{array}$ & P-value & Correlation & $\begin{array}{c}\text { T-value } \\
\text { (bootstrap) }\end{array}$ & $\begin{array}{c}\text { Variance } \\
\text { explained (\%) }\end{array}$ & $\begin{array}{l}\text { Supported } \\
\text { (yes/no) }\end{array}$ \\
\hline $\begin{array}{l}\text { H1: CSR information } \rightarrow \text { Social } \\
\text { dimension initiatives }\end{array}$ & $0.414 * * *$ & 0.000 & 0.414 & 7.643 & $17.14 \%$ & Yes \\
\hline $\begin{array}{l}\text { H2: CSR information } \rightarrow \text { Economic } \\
\text { dimension initiatives }\end{array}$ & $0.324 * * *$ & 0.000 & 0.324 & 6.097 & $10.50 \%$ & Yes \\
\hline \multicolumn{7}{|l|}{ H3: CSR information $\rightarrow$} \\
\hline $\begin{array}{l}\text { Environmental dimension } \\
\text { initiatives }\end{array}$ & $0.324 * * *$ & 0.000 & 0.462 & 7.008 & $14.97 \%$ & Yes \\
\hline $\begin{array}{l}\text { H4: Social dimension initiatives } \\
\rightarrow \text { CSR diffusion }\end{array}$ & $0.299 * * *$ & 0.001 & 0.486 & 3.716 & $14.53 \%$ & Yes \\
\hline $\begin{array}{l}\text { H5: Economic dimension } \\
\text { initiatives } \rightarrow \text { CSR diffusion }\end{array}$ & -0.067 & 0.504 & 0.336 & 0.728 & $2.25 \%$ & No \\
\hline $\begin{array}{l}\text { H6: Environmental dimension } \\
\text { initiatives } \rightarrow \text { CSR diffusion }\end{array}$ & $0.380 * * *$ & 0.000 & 0.526 & 3.295 & $19.99 \%$ & Yes \\
\hline
\end{tabular}

Note: ${ }^{*} p<0.05 ;{ }^{* *} p<0.01 ;{ }^{* * *} p<0.001$; based on a Student's $t_{(4999)}$ one-tailed distribution; $t_{(0,05,4999)}=1.645 ; t_{(0,01,4999)}=2.327 ; t_{(0,001,4999)}=3.092$

Source: Authors

but ideally greater than 0.3. However, Falk \& Miller (1992) are less demanding, suggesting that, in empirical research, one variable has a predictive effect on another when the first variable explains at least $1.5 \%$ of the endogenous variable's variance (see Table 6). In the present study, the $\beta$ values were $0.299,0.324,0.324,0.380,0.414$, and -0.067 , with only one value not meeting Chin's (1998b) recommended minimum (i.e., H5). If Falk \& Miller's (1992) criteria are applied, the variance explained can be seen to vary between $10.50 \%, 14.53 \%, 14.97 \%, 17.25 \%$, and $19.99 \%$, resulting in a value of $2.25 \%$ that, although it exceeds the recommended minimum of $1.5 \%$, is quite low but that suggests the results do not support all the hypotheses.

Analysis of the paths' significance can also be used to verify if empirical support exists for the set of hypotheses formulated. If the path coefficients (i.e., $\beta$ ) are significant, the hypotheses are supported. To carry out this analysis, a nonparametric resampling technique (i.e., a bootstrapping procedure) was applied, which provided both the standard error and values of the Student's $t$-statistic for the parameters. The analysis required a bootstrap test of 5,000 subsamples and used a Student's $t$-distribution. The latter was based on a tail with $n-1$ degrees of freedom, in which $n$ is the number of subsamples (Chin, 1998a; Hair et al., 2011). The present test was conducted with the sample data, producing quite satisfactory results, although a confirmation of all the hypotheses posited in this research would have been preferable.

Table 6 reveals that all but one of the structural paths proposed in the model are significant, although with different levels of significance. Thus, 5 out of 6 of the model's hypotheses are supported by the results. Despite the lack of a significant direct link between CSR economic initiatives with CSR diffusion (i.e., a $\beta$ value of -0.067 and a $p$-value of 0.504 ), the other 5 relationships were validated by the data, confirming SMEs' strong contribution to CSR. For H1, H2, H3, H4, and $\mathrm{H6}$, the variables' significant positive effects were confirmed with $\beta$ values of $0.299,0.324,0.324,0.380$, and 0.414 , respectively, and a $p$-value of less than 0.001 .

The bootstrapping procedure was used to analyze the percentile confidence intervals (CI), as well as the bias corrected. These values exceed a zero value, as recommended by Chin (1998a) (see Table 7).

In addition, the models' predictive power and goodness of fit were checked. According to Chin (2010), a model's goodness of fit is determined based on each structural path's strength and analyzed by calculating the value of $R^{2}$, namely,
Table 7. Percentile CI and/or bias corrected CI

\begin{tabular}{|c|c|c|c|c|c|}
\hline Hypothesis & $\begin{array}{c}\text { Path } \\
\text { coefficient } \\
(\beta)\end{array}$ & $\begin{array}{c}\text { Percentile } \\
\text { CI 5.0\% }\end{array}$ & $\begin{array}{l}\text { Percentile } \\
\text { CI } 95.0 \%\end{array}$ & $\begin{array}{c}\text { Bias } \\
\text { corrected } \\
\text { CI } 5.0 \% \\
\end{array}$ & $\begin{array}{c}\text { Bias } \\
\text { corrected } \\
\text { CI } 95.0 \% \\
\end{array}$ \\
\hline $\begin{array}{l}\text { H1: CSR information } \\
\rightarrow \text { Social dimension } \\
\text { initiatives }\end{array}$ & $0.414 * * *$ & 0.317 & 0.527 & 0.317 & 0.528 \\
\hline $\begin{array}{l}\text { H2: CSR information } \\
\rightarrow \text { Economic } \\
\text { dimension initiatives }\end{array}$ & $0.324 * * * *$ & 0.224 & 0.450 & 0.219 & 0.446 \\
\hline $\begin{array}{l}\text { H3: CSR information } \\
\rightarrow \text { Environmental } \\
\text { dimension initiatives }\end{array}$ & $0.324 * \cdots *$ & 0.371 & 0.575 & 0.373 & 0.578 \\
\hline $\begin{array}{l}\text { H4: Social dimension } \\
\text { initiatives } \rightarrow \text { CSR } \\
\text { diffusion }\end{array}$ & $0.299 * * * *$ & 0.130 & 0.458 & 0.125 & 0.467 \\
\hline $\begin{array}{l}\text { H5: Economic } \\
\text { dimension initiatives } \\
\rightarrow \text { CSR diffusion }\end{array}$ & -0.067 & -0.219 & 0.105 & -0.231 & 0.103 \\
\hline $\begin{array}{l}\text { H6: Environmental } \\
\text { dimension initiatives } \\
\rightarrow \text { CSR diffusion } \\
\end{array}$ & $0.380^{* * * *}$ & 0.256 & 0.532 & 0.251 & 0.534 \\
\hline
\end{tabular}

Note: ${ }^{*} p<0.05 ;{ }^{* *} p<0.01 ;{ }^{* * *} p<0.001$; based on a Student's $t_{(4999)}$ one-tailed distribution; $t_{(0,05,4999)}=1.645 ; t_{(0,01,4999)}=2.327 ; t_{(0,001,4999)}=3.092$ Source: Authors

the variance explained by the latent dependent variables. For each path or relationship between constructs, the $R^{2}$ values must be at least equal to or greater than 0.1 (Falk \& Miller, 1992). This condition was met, thereby confirming that the proposed and analyzed model has adequate predictive power. Table 8 shows the $R^{2}$ values calculated for the dependent constructs included in the structural model. According to Falk \& Miller's (1992) guidelines, all the dependent constructs should have appropriate $R^{2}$ values exceeding the minimum value of 0.1

To measure the significance of the dependent constructs' predictive power, PLS uses Stone-Geisser's $Q^{2}$ as a criterion. This index is calculated based on the redundancies that result from the product of communalities $\left(\lambda^{2}\right)$ with the AVE, which is obtained through cross-loading analysis. According to Chin (2010) and Hair et al. (2011), the $Q^{2}$ value is calculated by following the blindfolding procedure, a technique that reuses the sample by omitting part of it and using the estimated result to predict the omitted part. The results need to be interpreted as follows (Chin, 2010; Hair et al., 2011). If $Q^{2}>0$, the model has predictive capability, but, if $Q^{2}<0$, the model has no predictive capability. This analysis's results are presented in Table 8. Based on Chin's (1998a) recom- 
mendations, the present results can be said to confirm that the constructs' predictive power is significant because positive $Q^{2}$ values were obtained.

Regarding the model's goodness of fit, various indices available for PLS can be used (Henseler, 2017; Henseler, Hubona \& Ray, 2016). Henseler et al. (2014) developed and empirically validated a global measure that can be applied in conjunction with PLS, namely, the standardized root mean square residual (SRMR). The indices d_ULS and d_G can also be utilized. Henseler et al. (2014) suggest that this measure's value should not exceed a maximum value of 0.08 .

In the present study, the SRMR was found to have a value of 0.08 , so the model's overall fit is satisfactory. In relation to the d_ULS and d_G fitness tests, values of 2.624 and 0.929 , respectively, were obtained (i.e., lower than the 95\% percentile), confirming that any existing discrepancy is not significant (see Table 8). Finally, the correlation value of the mean square error (i.e., RMStheta) was analyzed (Henseler, Hubona, \& Ray, 2016). In the current research, this indicator achieved a value of 0.124 . This indicator must be quite close to 0 and less than 0.12 . The value obtained is, nonetheless, considered to be within the required margins (Henseler, Ringle, \& Sarstedt, 2016) (see Table 7 above). The tests carried out confirmed that the global model is a good fit for the data and well aligned with the existing theory. Table 8 lists the results of the different fitness tests.

Table 8. Predictive power and model fit

\begin{tabular}{lcccccc}
\hline \multicolumn{1}{c}{ Constructs } & $\begin{array}{c}\mathrm{R}^{2} \text { (explained } \\
\text { variance) }\end{array}$ & $\begin{array}{c}\mathrm{Q}^{2} \text { (1- } \\
\text { SSE/SSO) }\end{array}$ & SRMR d_ULS & d_G & RMStheta \\
\hline CSR diffusion & 0.323 & 0.169 & & & & \\
$\begin{array}{l}\text { Social dimension } \\
\begin{array}{l}\text { Economic } \\
\text { dimension }\end{array}\end{array}$ & 0.171 & 0.094 & & & & \\
$\begin{array}{l}\text { Environmental } \\
\text { dimension }\end{array}$ & 0.105 & 0.056 & 0.0 & 2.62 & 0.92 & 0.124 \\
\hline
\end{tabular}

Note: $\mathrm{R}^{2}=$ coefficient of determination; SSE/SSO: sum of squared prediction errors/sum of the squared observations

Source: Authors

\section{Discussion}

We consider that to carry out this research is relevant given the importance for any company of having information on the actions it undertakes. In this case, it is important that every company that implements a CSR strategy is perfectly informed of what this entails, of the advantages but also of the costs that may be incurred. Likewise, once the initiatives have been undertaken, it is essential to carry out a diffusion of the actions carried out. This contributes to improving the competitive advantage of the company while giving it legitimacy. Therefore, both the information on CSR and the disclosure made are necessary and essential aspects of CSR. This has allowed us to analyze it from the perspective of MO, linking it with the response offered by the company, following the model of Kholi \& Jaworski (1990) and Slater \& Narver (2000).

In the present study, the majority of the hypotheses were validated (i.e., except for H5). CSR information contributes to the development of CSR initiatives in three dimensions: social, economic, and environmental. Managers who gather CSR information can implement initiatives that benefit all stakeholders (Kiessling et al., 2016; Martínez-Martínez et al., 2017; Öberseder et al., 2011), as posited by the stakeholders theory. These managers also properly manage resources, thereby contributing to the creation of value (Asher et al., 2005) and offering appropriate responses to the globalized market to which their companies belong (Richter \& Dow, 2017). When the dynamic capabilities theory is supported by information use and the generation of initiatives, firms can develop a higher level of CSR by defining and exploring opportunities for action, applying available resources, and achieving sustainable performance (Kachouie et al., 2018; Teece, 2007), as posited by dynamic capabilities theory. Therefore, the development of social and environmental initiatives leads to CSR diffusion through reports offering significant contributions to stakeholder value (Galbreath, 2009; Ramachandran, 2011).

The current findings confirm that collecting CSR information contributes to CSR initiatives and constitutes a valuable asset (Gallardo-Vázquez \& Sánchez-Hernández, 2014b), including the beneficial results that this strategy produces (Duff, 2017; Ghouri et al., 2019). Concurrently, the present findings confirm that the development of social and environmental initiatives contributes positively to CSR dissemination, which agrees with numerous authors' results (e.g., Brunton et al., 2017; Thijssens et al., 2015). This relationship can further contribute to the generation of competitive advantages (Gamerschlag et al., 2011; Siueia et al., 2019).

The paper contributes to define a possible relationship between MO and socially responsible practices, improving the emphasis on sustainability (Barone et al., 2007; Oduro \& Haylemariam, 2019). This way, this new perspective offers a better and current understanding of firms' CSR strategies (Kholi \& Jaworski, 1990; Narver \& Slater, 1990). We consider that the literature on MO and CSR have improved with this paper, adding to previous research (Luo \& Bhattacharya, 2009). The application of the two theories considered in the theoretical framework, stakeholders and dynamic capabilities theories, make a valuable contribution, adding new empirical evidence on the applications of these theories.

\section{Conclusions, limitations, and future lines of research}

The present study sought to discover whether companies gather enough CSR information to facilitate the implementation of CSR initiatives. Therefore, this research had two objectives. The first was to achieve a better understanding of how companies' CSR information influences their development of CSR initiatives based on the triple bottom line perspective. Three hypotheses were defined, which all received support. This objective's fulfillment provided answers to the first two RQs (i.e., RQ1 and RQ2), confirming that companies collect enough CSR information to implement appropriate strategies. The information gathered allows companies to define a complete set of activities based on the triple dimension approach.

The second objective was to analyze the relationship between the development of CSR initiatives and CSR diffusion. Three further hypotheses were formulated, of which two were supported. No empirical support was found for a direct, positive relationship between the development of economic initiatives and companies' dissemination of CSR information. This result answered the third research question (i.e., RQ3), verifying that, once companies have carried out social and environmental CSR initiatives, these firms can disseminate the relevant information to stakeholders. However, this link cannot be confirmed for companies' implementation of economic initiatives.

Overall, the results confirm an important link exists between information, response, and diffusion, which constitutes an extension of Kholi \& Jaworski (1990) and Narver 
and Slater's (1990) conceptualization of the MO strategy. The findings thus provide a vision of CSR in line with previous authors but also differing from their perspectives. For example, Gallardo-Vázquez \& Sánchez-Hernández (2014b) only analyzed companies' response in terms of environmental concerns. Sánchez-Hernández et al. (2019) used a smaller sample in a business context that discourages socially responsible behaviors linked to CSR legislation. The present research contributes to the literature by uniting the two cited studies' visions, analyzing firms' response in all three areas of the triple bottom line-economic, social, and environmental-and collecting data on companies in a region actively promulgating a CSR law.

Most organizations and SMEs are fighting to obtain more valuable information that will allow them to improve their social, economic, and environmental CSR initiatives. Thus, this study's findings have theoretical and practical implications. First, the results contribute to CSR research's expansion from a holistic point of view, namely, from the triple bottom line perspective. The research's results contribute to defining the steps that companies must follow in their CSR practices, including the moment information can be gathered about these. The findings contribute to and facilitate the continuous development of different theoretical trends in analyses of CSR practices, more specifically, from a collaborative angle that considers employees, investors, customers, suppliers, and communities. This study thus confirmed the viability of extending the MO perspective to include social responsibility strategies, in conjunction with a multi-stakeholder approach.

From a practical perspective, the results have the following implications. First, SMEs need to continue any internal practices that help these firms to capture information, as well as encouraging a corporate culture that includes developing CSR initiatives that benefit all stakeholders. Second, SMEs' managers are clearly committed to adopting CSR practices as a way to help their companies improve their internal processes and use the correct mechanisms to communicate their most beneficial social and environmental initiatives. Third, to strengthen their dissemination of economic initiatives, SMEs should adopt new forms of communication based on innovative technologies in order to improve their organizational practices.

Last, the present results contribute to developing a more interdisciplinary perspective by successfully linking MO (Kholi \& Jaworski, 1990; Narver \& Slater, 1990) with a sustainable perspective. Thus, the current study added to the previous work done by Gallardo-Vázquez \& Sánchez-Hernández (2014b), Bello et al. (2018), Kiessling et al. (2016), and Sánchez-Hernández et al. (2019), presenting a perspective that broadens the existing research and explains how managers can control the information they have by managing, applying, and disseminating it.

Regardless of the above contributions, the present study had some limitations. The first limitation was that the answers reflected each SME leader's subjective opinion, so the data collected may have retained their bias. The second limitation was that the variables' measurement was dealt with through reflective models using the PLS technique based on variance. Future extensions of this research could thus benefit from including analyses based on covariance. The last limitation is that only Spanish companies already oriented toward CSR participated in the study.

Given the above results and limitations, this study's approach may be worth developing further by including new constructs that expand the existing knowledge about this topic. Future research could also analyze the proposed model from different angles at various regional and global levels. More specifically, the present approach could be applied to examine CSR further by incorporating issues related to the circular economy and eco-innovation.

\section{Acknowledgment}

We wish to convey our thanks to Martín Gamero Pardo for facilitating this research through his relationships with the companies under study.

\section{Funding}

The authors would like to express their gratitude to the European Regional Development Fund and Junta of Extremadura for their financial support and, more specifically, for the funds provided by the Business Research (INVE) Research Group (SEJ022 code) and by the VI Action Plan 20182020 (GR18058).

\section{Conflict of interests}

The authors declare no conflict of interests.

\section{References}

Andrades Peña, J., \& Larrán Jorge, M. (2019). Examining the amount of mandatory non-financial information disclosed by Spanish state-owned enterprises and its potential influential variables. Meditari Accountancy Research, 27(4), 534-555. https://doi.org/10.1108/ MEDAR-05-2018-0343

Andrades, J., Martínez-Martínez, D., Larrán, M., \& Herrera, J. (2019). Online information disclosure in Spanish municipal-owned enterprises: A study based on the compliance with transparency requirements. Online Information Review, (in press). https://doi.org/10.1108/ OIR-02-2018-0063

APCO Worldwide. (2004). Communicating CSR: Talking to people who listen, global CSR study. Retrieved from [www.apcoworldwide.com

Asher, C., Mahoney, J.M., \& Mahoney, J.T. (2005). Towards a property rights foundation for a stakeholder theory of the firm. Journal of Management Governance, 9(1), 5-32. https://doi.org/10.1007/s10997-005-1570-2

Baldarelli, M. G., \& Gigli, S. (2014). Exploring the drivers of corporate reputation integrated with a corporate responsibility perspective: Some reflections in theory and in praxis. Journal of Management \& Governance, 18(2), 589-613. https://doi.org/10.1007/s10997-011-9192-3

Barone, M.J., Norman, A.T., \& Miyazaki, A.D. (2007). Consumer response to retailer use of causerelated marketing: is more fit better?. Journal of Retailing, 83(4), 437-445.

Bello, T. A., Halim, F., \& Alshuabi, A. I. (2018). The relationship between market orientation dimensions and performance of micro finance institutions. Journal of Marketing Management and Consumer Behavior, 2(3), 1-14.

Bhaduri, S. N., \& Selarka, E. (2016). Corporate governance: An overview. In S. N. Bhaduri, \& E. Selarka (Eds.), Corporate governance and corporate social responsibility of Indian companies (pp. 61-72). Singapore: Springer.

Bhatia, K., \& Jain, P. (2015). A study of performance appraisal and organizational effectiveness in terms of indi- 
vidual and organizational basis. A comparative study of BSNL and AIRTEL. International Journal on Arts, Management and Humanities, 8(1), 23-39.

Bitencourt, C.C., Santini, F.D., Ladeira, W., Santos, A.C., \& Teixeira, E.K. (2020). The extended dynamic capabilities model: A meta-analysis. European Management Journal, 38(1), 108-120. https://doi.org/10.1016/j.emj.2019.04. 007

Blanc, R., Branco, M. C., \& Patten, D. M. (2019). Cultural secrecy and anti-corruption disclosure in large multinational companies. Australian Accounting Review, 29(2), 438-448. https://doi.org/10.1111/auar.12231

Bondy, K., Moon, J., \& Matten, D. (2012). An Institution of Corporate Social Responsibility (CSR) in multinational corporations (MNCs): Form and implications. Journal of Business Ethics, 111(2), 281-299. DOI:10. 1007/s10551-012-1208-7

Boulouta, I., \& Pitelis, C. N. (2014). Who needs CSR? The impact of corporate social responsibility on national competitiveness. Journal of Business Ethics, 119(3), 349-364. https://doi.org/10.1007/s10551-013-1633-2

Brady, M. K., \& Cronin Jr, J. J. (2001). Customer orientation: Effects on customer service perceptions and outcome behaviors. Journal of service Research, 3(3), 241251. https://doi.org/10.1177/109467050133005

Brunsson, N., Rasche, A., \& Seidl, D. (2012). The dynamics of standardization: Three perspectives on standards in organization studies. Organization Studies, 33(5-6), 613632. https://doi.org/10.1177/0170840612450120

Brunton, M., Eweje, G., \& Taskin, N. (2017). Communicating corporate social responsibility to internal stakeholders: Walking the walk or just talking the talk? Business Strategy and the Environment, 26(1), 31-48. [https: //doi.org/10.1002/bse.1889

Cabeza-García, L., Sacristán-Navarro, M., \& Gómez-Ansón, S. (2017). Family involvement and corporate social responsibility disclosure. Journal of Family Business Strategy, 8(2), 109-122. https://doi.org/10.1016/j.jbs.2017.04. 002

Campos, C., \& Grangel, R. (2019). Corrigendum to "A domain-specific modelling language for Corporate Social Responsibility (CSR)" [Comput. Ind. 97 (2018) 97110]. Computers in Industry, 108, 221. https://doi.org/ 10.1016/j.compind.2018.01.007

Carroll, A. B., \& Shabana, K. M. (2010). The business case for corporate social responsibility: A review of concepts, research and practice. International Journal of Management Reviews, 12(1), 85-105. https://doi.org/10.1111/j. 1468-2370.2009.00275.x

Cea Moure, R. (2019). CSR communication in Spanish quoted firms. European Research on Management and Business Economics, 25(2), 93-98. https://doi.org/10. $1111 /$ jsbm.12450

Corazza, L. (2019). The Standardization of Down-Streamed Small Business Social Responsibility (SBSR): SMEs and Their Sustainability Reporting Practices. In M. KhosrowPour (Ed.), Social Entrepreneurship: Concepts, Methodologies, Tools, and Applications (pp. 670-685). USA: IGI Global.

Chin, W. W. (1998a). The partial least squares approach to structural equation modeling. In G. A. Marcoulides (Ed.), Modern methods for business research (pp. 295336). Hillsdale, NJ: Lawrence Erlbaum.

Chin, W. W. (1998b). Issues and opinion on structural equation modeling. MIS Quarterly, 22(1), VII-XVI.

Chin, W. W. (2010). How to write up and report PLS analyses.
In V. Esposito, W. W. Chin, J. Henseler, \& H. Wang (Eds.), Handbook of partial least squares: Concepts, methods and applications in marketing and related fields (pp. 655690). Berlin: Springer.

Chin, W. W., \& Dibbern, J. (2010). An introduction to a permutation based procedure for multi-group PLS analysis: Results of tests of differences on simulated data and a cross cultural analysis of the sourcing of information system services between Germany and the USA. In V. Esposito, W. W. Chin, J., Henseler, \& H. Wang (Eds.), Handbook of partial least squares: Concepts, methods and applications in marketing and related fields (pp. 171-193). Berlin: Springer.

Dentoni, D., Bitzer, V., \& Pascucci, S. (2016). Crosssector partnerships and the co-creation of dynamic capabilities for stakeholder orientation. Journal of Business Ethics, 135(1), 35-53. https://doi.org/10.1007/ s10551-015-2728-8

Directorio Central de Empresas (DIRCE) (2016). Dirección General de Industria y de la Pequeña y Mediana Empresa. Gobierno de España.

Du, S., Bhattacharya, C.B., \& Sen, S. (2007). Reaping relational rewards from corporate social responsibility: the role of competitive positioning. International Journal of Research in Marketing, 24(3), 224-241. https://doi.org/ 10.1016/j.ijresmar.2007.01.001

Du, S., Bhattacharya, C. B., \& Sen, S. (2010). Maximizing business returns to corporate social responsibility (CSR): The role of CSR communication. International Journal of Management Reviews, 12(1), 8-19. https://doi.org/10. $1111 / \mathrm{j} .1468-2370.2009 .00276 . x$

Duff, A. (2017). Corporate social responsibility as a legitimacy maintenance strategy in the professional accountancy firm. The British Accounting Review, 49(6), 513-531. https://doi.org/10.1016/j.bar.2017.08.001

European Commission. (2002). European SMEs and social and environmental responsibility. Observatory of European SMEs 2002/No 4. Luxembourg.

Fassin, Y., de Colle, S., \& Freeman, R. E. (2016). Intrastakeholder alliances in plant-closing decisions: A stakeholder theory approach. Business Ethics: A European Review, 26(2), 97-111. https://doi.org/10.1111/beer. 12136

Falk, R. F., \& Miller, N. B. (1992). A primer for soft modeling. Akron, OH: University of Akron Press.

Fisher, K., Geenen, J., Jurcevic, M., McClintock, K., \& Davis, G. (2009). Applying asset-based community development as a strategy for CSR: A Canadian perspective on a win-win for stakeholders and SMEs. Business Ethics: A European Review, 18(1), 66-82. https://doi.org/10. 1111/j.1467-8608.2009.01549.x

Fornell, C., \& Larcker, D. F. (1981). Evaluating structural equation models with unobservable variables and measurement error. Journal of Marketing Research, 18(1), 3950. https://www.jstor.org/stable/3151312

Freeman, R.E. (1998). A stakeholder theory of the modern corporation. In L.B. Pincus (Ed.), Perspectives in Business Ethics (pp. 171-181). Singapore: McGraw-Hill.

Freeman, R.E. (1999). Divergent Stakeholder Theory. Academy of Management Review, 24(2), 233-236. DOI: /10.5465/amr.1999.1893932

Freeman, R., \& Philips, R. (2002). Stakeholder theory: A libertarian defense. Business Ethics Quarterly, 12(3), 331349. https://www.jstor.org/stable/3858020

Frynas, J. G., \& Yamahaki, C. (2016). Corporate social responsibility: Review and roadmap of theoretical perspect- 
ives. Business Ethics: A European Review, 25(3), 258-285. https://doi.org/10.1111/beer.12115

Galbreath, J. (2009). Building corporate social responsibility into strategy. European business review, 21(2), 109-127. https://doi.org/10.1108/09555340910940123

Gallardo-Vázquez, D., Sánchez-Hernández, \& M.I., Corchuelo Martínez-Azúa, M.B. (2013). Validation of a measurement scale for the relationship between the orientation to corporate social responsibility and other business strategic variables, Spanish Accounting Review, 16(1), 11-23. https://doi.org/10.1016/S1138-4891(13)70002-5

Gallardo-Vázquez, D., \& Sánchez-Hernández, M. I. (2014a). Measuring corporate social responsibility for competitive success at a regional level. Journal of Cleaner Production, 72, 14-22. https://doi.org/10.1016/j.jclepro.2014. 02.051

Gallardo-Vázquez, D., \& Sánchez-Hernández, M. I. (2014b). Structural analysis of the strategic orientation to environmental protection in SMEs. BRQ Business Research Quarterly, 17(2), 115-128. https://doi.org/10.1016/j. brq.2013.12.001

Gamerschlag, R., Möller, K., \& Verbeeten, F. (2011). Determinants of voluntary CSR disclosure: Empirical evidence from Germany. Review of Managerial Science, 5(2-3), 233262. https://doi.org/10.1007/s11846-010-0052-3

Gangi, F., Meles, A., Monferrà, S., \& Mustilli, M. (2018). Does corporate social responsibility help the survivorship of SMEs and large firms?. Global Finance Journal, 100402. https://doi.org/10.1016/j.gfj.2018.01.006

Ghouri, A. M., Akhtar, P., Shahbaz, M., \& Shabbir, H. (2019). Affective organizational commitment in global strategic partnerships: The role of individual-level microfoundations and social change. Technological Forecasting and Social Change, 146, 320-330. https://doi.org/10.1016/ j.techfore.2019.05.025

Grinstein, A. (2008). The effect of market orientation and its components on innovation consequences: a meta-analysis. Journal of the Academy of Marketing Science, 36(2), 66-173. https://doi.org/10.1007/ s11747-007-0053-1

Hair, J. F., Black, W. C., Babin, B. J., Anderson, R. E., \& Tatham, R. L. (2006). Multivariate data analysis (Vol. 6). Upper Saddle River, NY: Pearson Prentice Hall.

Hair Jr, J. F., Black, W. C., Babin, B. J., Anderson, R. E., \& Tatham, R. L. (2010). SEM: An introduction. In J. F. Hair Jr, W. C. Black, B. J. Babin, \& R. E. Anderson (Eds.), Multivariate data analysis: A global perspective (pp. 629686). Upper Saddle River, NY: Pearson Prentice Hall.

Hair, J. F., Ringle, C. M., \& Sarstedt, M. (2011). PLSSEM: Indeed a silver bullet. Journal of Marketing Theory and Practice, 19(2), 139-152. https://doi.org/10.2753/ MTP1069-6679190202

Hair, J. F., Risher, J. J., Sarstedt, M., \& Ringle, C. M. (2019). When to use and how to report the results of PLS-SEM. European Business Review, 31, 2-24. https://doi.org/10. 1108/EBR-11-2018-0203

Hammann, E. M., Habisch, A., \& Pechlaner, H. (2009). Values that create value: Socially responsible business practices in SMEs-empirical evidence from German companies. Business Ethics: A European Review, 18(1), 37-51. https://doi.org/10.1111/j.1467-8608.2009.01547.x

Hameed, I., Riaz, Z., Arain, G.A., \& Farooq, O. (2016). How do internal and external CSR affect employeest' organizational identification? A perspective from the group engagement model. Frontiers in Psychology, 7, 1-13. https:

\section{//doi.org/10.3389/fpsyg.2016.00788}

Hao, Y., Farooq, Q., \& Zhang, Y. (2018). Unattended social wants and corporate social responsibility of leading firms: Relationship of intrinsic motivation of volunteering in proposed welfare programs and employee attributes. Corporate Social Responsibility and Environmental Management, 25(6), 1029-1038. https://doi.org/10.1002/csr.1681

Henseler, J. (2017). Bridging Design and Behavioral Research with Variance-Based Structural Equation Modeling. Journal of Advertising, 46, 178-192.

Henseler, J., Dijkstra, T. K., Sarstedt, M., Ringle, C. M., Diamantopoulos, A., Straub, D. W., . . . Calantone, R. J. (2014). Common beliefs and reality about PLS comments on Rönkkö and Evermann (2013). Organizational Research Methods, 17(2), 182-209. https://doi.org/10. $1177 / 1094428114526928$

Henseler, J., Hubona, G., \& Ray, P.A. (2016). Using PLS path modeling in new technology research: Updated guidelines. Industrial Management \& Data System, 116, 2-20. https://doi.org/10.1108/IMDS-09-2015-0382

Henseler, J., Ringle, C. M., \& Sarstedt, M. (2015). A new criterion for assessing discriminant validity in variancebased structural equation modeling. Journal of the Academy of Marketing Science, 43(1), 115-135. https: //doi.org/10.1007/s11747-014-0403-8

Henseler, J., Ringle, C.M., \& Sarstedt, M. (2016). Testing measurement invariance of composites using partial least squares. International Marketing Review, 33, 405-431.

Herrera-Madueño, J., Larrán-Jorge, M., Lechuga-Sancho, M.P., \& Martínez-Martínez, D. (2016). Responsabilidad social en las PYMEs: análisis exploratorio de factores explicativos. Revista de Contabilidad, 19(1), 31-44. https: //doi.org/10.1016/j.rcsar.2014.10.003

Im, S., \& Workman Jr, J. P. (2004). Market orientation, creativity, and new product performance in high-technology firms. Journal of Marketing, 68(2), 114-132.

Jeurissen, R. (2000). John Elkington, Cannibals with forks: The triple bottom line of $21^{\text {st }}$ century business. Journal of Business Ethics, 23(2), 229-231. https://doi.org/10. 1023/A:1006129603978

Jiang, W., Rosati, F., Chai, H., \& Feng, T. (2020). Market orientation practices enhancing corporate environmental performance via knowledge creation: Does environmental management system implementation matter? Business Strategy and the Environment, (in press).

Jo, H., Kim, H., \& Park, K. (2015). Corporate environmental responsibility and firm performance in the financial services sector. Journal of Business Ethics, 131(2), 257-284. https://doi.org/10.1007/s10551-014-2276-7

Jogaratnam, G. (2017). How organizational culture influences market orientation and business performance in the restaurant industry. Journal of Hospitality and Tourism Management, 31, 211-219. https://doi.org/10.1016/ j.jhtm.2017.03.002

Johnstone, L. (2019). A systematic analysis of environmental management systems in SMEs: Possible research directions from a management accounting and control stance. Journal of Cleaner Production, 244. https://doi.org/10. 1016/j.jclepro.2019.118802

Jones, D. A. (2010). Does serving the community also serve the company? Using organizational identification and social exchange theories to understand employee responses to a volunteerism programme. Journal of Occupational and Organizational Psychology, 83(4), 857-878. https: //doi.org/10.1348/096317909X477495

Kachouie, R., Mavondo, F., \& Sands, S. (2018). Dynamic 
marketing capabilities view on creating market change. European Journal of Marketing, 52(5/6), 1007-1036. https://doi.org/10.1108/EJM-10-2016-0588

Kajalo, S., \& Lindblom, A. (2015). Market orientation, entrepreneurial orientation and business performance among small retailers. International Journal of Retail \& Distribution Management, 43(7), 580-596. https://doi.org/10. 1108/IJRDM-04-2014-0044

Kang, J. (2009). Corporate social responsibility? Not my business any more: The CEO horizon problem in corporate social performance. Academy of Management Perspectives, 1, 1-6.

Kholi, A., \& Jaworski, B. (1990). Market orientation: The construct, research propositions and marketing management implications. Journal of Marketing, 54(2), 1-18. https://doi.org/10.1177/002224299005400201

Kiessling, T., Isaksson, L., \& Yasar, B. (2016). Market orientation and CSR: Performance implications. Journal of Business Ethics, 137(2), 269-284. https://doi.org/10.1007/ s10551-015-2555-y

Kirca, A. H., Jayachandran, S., \& Bearden, W. O. (2005). Market orientation: A meta-analytic review and assessment of its antecedents and impact on performance. Journal of Marketing, 69(2), 24-41.

Kouloukoui, D., Sant'Anna, A. M., Gomes, S. M., Marinho, M. M. D., de Jong, P., Kiperstok, A., \& Torres, E. A. (2019). Factors influencing the level of environmental disclosures in sustainability reports: Case of climate risk disclosure by Brazilian companies. Corporate Social Responsibility and Environmental Management, 26(4), 791-804. https: //doi.org/10.1002/csr.1721

Larrán Jorge, M., Andrades Peña, F. J., \& Herrera Madueño, J. (2019). An analysis of university sustainability reports from the GRI database: an examination of influential variables. Journal of Environmental Planning and Management, 62(6), 1019-1044. DOI. https://doi.org/10.1080/ 09640568.2018 .1457952

Law 15/2010, of December 9, on Corporate Social Responsibility in Extremadura. DOE of December 15, 2010.

Lechuga-Sancho, M.P., Martínez-Martínez, D., Larrán Jorge, M., \& Herrera Madueño, J. (2018). Understanding the link between socially responsible human resource management and competitive performance in SMEs. Personnel Review, 47(10), 1211-1243. https://doi.org/10. 1108/PR-05-2017-0165

Ledesma-Chaves, P., Arenas-Gaitan, J., \& García-Cruz, R. (2020). International expansión: mediation of dynamic capabilities. Marketing Intelligence \& Planning, 02634503. https://doi.org/I 10.1108/MIP-05-2019-0269 (in press).

Liao, S.-H., Chang, W.-J., Wu, C.-C., \& Katrichis, J. M. (2011). A survey of market orientation research (1995-2008). Industrial Marketing Management, 40, 301-310. https:// doi.org/10.1016/j.indmarman.2010.09.003

Liu, Y., Li, J., Quan, B., \& Yang, J. (2019). Decision analysis and coordination of two-stage supply chain considering cost information asymmetry of corporate social responsibility. Journal of Cleaner Production, 228, 1073-1087. https://doi.org/10.1016/j.jclepro.2019.04.247

LópezPérez, M.E., Melero, I., \& Sese, F.J. (2017). Management for sustainable development and its impact on firm value in the SME context: does size matter?. Business Strategy and the Environment, 26(7), 985-99. https: //doi.org/10.1002/bse.1961

Luo, X., \& Bhattacharya, C. B. (2009). The debate over doing good: Corporate social performance, strategic marketing levers, and firm-idiosyncratic risk. Journal of Marketing, 73, 198-213. https://www.jstor.org/stable/20619069

Marín, L., Rubio, A., \& Ruiz de Maya, S. (2012). Competitiveness as a strategic outcome of corporate social responsibility. Corporate Social Responsibility and Environmental Management, 19(6), 364-76.

Martínez-Conesa, I., Soto-Acosta, P., \& Palacios-Manzano, M. (2017). Corporate social responsibility and its effect on innovation and firm performance: an empirical research in SMEs. Journal of Cleaner Production, 142(4), 23742383. https://doi.org/10.1016/j.jclepro.2016.11.038

Martínez-Ferrero, J. (2014). Consecuencias de las prácticas de sostenibilidad en el coste de capital y en la reputación corporativa. Spanish Accounting Review, 17(2), 153-162. https://doi.org/10.1016/j.rcsar.2013.08.008

Martínez-Martínez, D., Herrera Madueño, J., Larrán Jorge, M., \& Lechuga Sancho, M.P. (2017). The strategic nature of corporate social responsibility in SMEs: a multiple mediator analysis. Industrial Management \& Data Systems, 117(1), 2-31. https://doi.org/10.1108/ IMDS-07-2015-0315

Moneva-Abadía, J. M., Gallardo-Vázquez, D., \& SánchezHernández, M. I. (2018). Corporate social responsibility as a strategic opportunity for small firms during economic crises. Journal of Small Business Management, 57(S2), 172-199.

Narver, J., \& Slater, S. (1990). The effect of a market orientation on business profitability. Journal of Marketing, 54(4), 20-35. [https://doi.org/10.2307/1251757

Nielsen, A. E., \& Thomsen, Ch. (2009). Investigating CSR communication in SMEs: A case study among Danish middle managers. Business Ethics: A European Review, 18(1), 83-93. https://doi.org/10.1111/j.1467-8608. 2009.01550.x

Nunnally, J. (1978). Psychometric methods. New York: McGraw-Hill.

Öberseder, M., Schlegelmilch, B., \& Gruber, V. (2011). Why don't consumers care about CSR?: A qualitative study exploring the role of CSR in consumption decisions. Journal of Business Ethics, 104(4), 449-460. https://doi.org/10. 1007/s10551-011-0925-7

Oduro, S., \& Haylemariam, L.G. (2019). Market orientation, CSR and financial and marketing performance in manufacturing firms in Ghana and Ethiopia. Sustainability Accounting, Management and Policy Journal, 10(3), 398-426. https://doi.org/10.1108/sampj-11-2018-0309

Patenaude, G. (2011). Climate change diffusion: While the world tips, business schools lag. Global Environmental Change, 21(1), 259-271. https://doi.org/10. 1016/j.gloenvcha.2010.07.010

Protcko, E., \& Dornberger, U. (2014). The impact of market orientation on business performance - the case of Tatarstan knowledge-intensive companies (Russia). Problems and Perspectives in Management, 12(4), 225-231.

Raju, P.S., Lonial, S.C., \& Crum, M.D. (2011). Market orientation in the context of SMEs: a conceptual framework. Journal of Business Research, 64(12), 1320-1326. https://doi.org/10.1016/j.jbusres.2010.12.002

Ramachandran, V. (2011). Strategic corporate social responsibility: a 'dynamic capabilities' perspective. Corporate Social Responsibility and Environmental Management, 18(5), 285-293. https://doi.org/10.1002/csr.251

Ramón-Llorens, M. C., García-Meca, E., \& Pucheta-Martínez, M. C. (2018). The role of human and social board capital in driving CSR reporting. Long Range Planning, 52(6), 
101846. Https://doi.org/10.1016/j.lrp.2018.08.001

Reverte, C. (2009). Determinants of corporate social responsibility disclosure ratings by Spanish listed firms. Journal of Business Ethics, 88(2), 351-366. https://doi.org/10. 1007/s10551-008-9968-9

Reverte, C., Gómez-Melero, E., \& Cegarra-Navarro, J.G. (2016). The influence of corporate social responsibility practices on organizational performance: evidence from eco-responsible Spanish firms. Journal of Cleaner Production, 112(4), 2870-2884. https://doi.org/10.1016/j. jclepro.2015.09.128

Rexhepi, G., Kurtishi, S., \& Bexheti, G. (2013). Corporate social responsibility (CSR) and innovation-the drivers of business growth?. Procedia-Social and Behavioral Sciences, 75, 532-541. https://doi.org/10.1016/j.sbspro.2013.04. 058

Richter, U.H., \& Dow, K.E. (2017). Stakeholder theory: A deliberative perspective. Business Ethics: A European Review, 26(4), 428-442. https://doi.org/10.1111/beer.12164

Ringle, C.M., Wende, S., \& Becker, J.M. (2014). SmartPLS 3. SmartPLS, Hamburg.

Roberts, P., Priest, H., \& Traynor, M. (2006). Reliability and validity in research. Nursing Standard, 20(44), 41-45. https://doi.org/10.7748/ns2006.07.20.44.41.c6560

Rodrigo, P., Durán, I. J., \& Arenas, D. (2016). Does it really pay to be good, everywhere? A first step to understand the corporate social and financial performance link in Latin American controversial industries. Business Ethics: A European Review, 25(3), 286-309. https://doi.org/10. 1111/beer.12119

Roldán, J.L., \& Sánchez-Franco, M.J. (2012). Variancebased structural equation modeling: Guidelines for using partial least squares in information systems research. In M. Mora, O. Gelman, A. Steenkamp, \& M. S. Raisinghani (Eds.), Research Methodologies, Innovations and Philosophies in Software Systems Engineering and Information Systems (pp. 193-221). USA: Hershey, PA.

Sakunasingha, B., Jiraporn, P., \& Uyar, A. (2018). Which CSR activities are more consequential? Evidence from the Great Recession. Finance Research Letters, 27, 161168. https://doi.org/10.1016/j.frl.2018.02.003

Sánchez-Hernández, M. I., Carvalho, L. C., \& Paiva, I. S. (2019). Orientation towards social responsibility of North-West African firms. Sustainability Accounting, Management and Policy Journal, 10(2), 365-394. https://doi. org/10.1108/SAMPJ-07-2018-0171

Sarkar, S., Coelho, D. M., \& Maroco, J. (2016). Strategic orientations, dynamic capabilities, and firm performance: an analysis for knowledge intensive business services. Journal of the Knowledge Economy, 7(4), 10001020. https://doi.org/10.1007/s13132-016-0415-3

Siueia, T. T., Wang, J., \& Deladem, T. G. (2019). Corporate social responsibility and financial performance: A comparative study in the Sub-Saharan Africa baking sector. Journal of Cleaner Production, 226, 658-668.

Sivarajah, U., Irani, Z., Gupta, S., \& Mahroof, K. (2019). Role of big data and social media analytics for business to business sustainability: A participatory web context. Industrial Marketing Management, (in press). https://doi.org/ 10.1016/j.indmarman.2019.04.005

Slater, S. F., \& Narver, J. C. (2000). Intelligence generation and superior customer value. Journal of the Academy of Marketing Science, 28(1), 120-127.

Smirnova, M., Naudé, P., Henneberg, S.C., Mouzas, S., \& Kouchtch, S.P. (2011). The impact of market orientation on the development of relational capabilities and perform- ance outcomes: the case of Russian industrial firms. Industrial Marketing Management, 40(1), 44-53.

Steinhöfel, E., Galeitzke, M., Kohl, H., \& Orth, R. (2019). Sustainability Reporting in German Manufacturing SMEs. Procedia Manufacturing, 33, 610-617. https://doi.org/ 10.1016/j.promfg.2019.04.076

Teece, D. J. (2007). Explicating dynamic capabilities: the nature and microfoundations of (sustainable) enterprise performance. Strategic Management Journal, 28(13), 1319-1350. https://doi.org/10.1002/smj

Teece, D. J. (2018). Dynamic capabilities as (workable) management systems theory. Journal of Management \& Organization, 24(3), 359-368. https://doi.org/10.1017/jmo. 2017.75

Thanasanborrisude, J., \& Phadoongsitthi, M. (2015). Firm characteristics and CSR disclosures: Case study in MAI firms. Journal of Accounting Profession, 11(30), 23-40.

Thijssens, T., Bollen, L., \& Hassink, H. (2015). Secondary stakeholder influence on CSR disclosure: An application of stakeholder salience theory. Journal of Business Ethics, 132(4), 873-891. https://doi.org/10.1007/ s10551-015-2623-3

Tsalis, T. A., Stylianou, M. S., \& Nikolaou, I. E. (2018). Evaluating the quality of corporate social responsibility reports: The case of occupational health and safety disclosures. Safety science, 109, 313-323.

Turker, D. (2009a). Measuring corporate social responsibility: A scale development study. Journal of Business Ethics, 85(4), 411-427. https://doi.org/10.1007/ s10551-008-9780-6

Turker, D. (2009b). How corporate social responsibility influences organizational commitment. Journal of Business Ethics, 89(2), 189-204. https://doi.org/10.1007/ s10551-008-9993-8

Vaitoonkiat, E., \& Charoensukmongkol, P. (2020). Stakeholder orientationt's contribution to firm performance. The moderating effect of perceived market uncertainty. Management Research Review. https://doi.org/10.1108/ MRR-07-2019-0296 (in press).

Valdez-Juárez, L.E. (2017). Corporate social responsibility: its effect on SMEs. Journal of Management and Sustainability, 7(3), 75-89. https://doi.org/10.5539/jms.v7n3p75

Valdez-Juárez, L. E., Gallardo-Vázquez, D., \& Ramos-Escobar, E. A. (2018). CSR and the supply chain: Effects on the results of SMEs. Sustainability, 10, 2356. https://doi. org/10.3390/su10072356

Vandenberg, R. J., \& Lance, C. E. (2000). A review and synthesis of the measurement invariance literature: Suggestions, practices, and recommendations for organizational research. Organizational Research Methods, 3(1), 4-70. https://doi.org/10.1177/109442810031002

Vega-Rodríguez, R.A., \& Rojas-Berrio, S.P. (2011). The impact of market orientation on the financial performance of MSMES (micro, small and medium enterprises) in Bogotá. Cuadernos de Administración (Universidad Del Valle), 27(46), 130-140.

Vidal, N. G., Bull, G. Q., \& Kozak, R. A. (2010). Diffusion of corporate responsibility practices to companies: The experience of the forest sector. Journal of Business Ethics, 94(4), 553-567. https://doi.org/10.1007/ s10551-009-0281-z

Vigneau, L., Humphreys, M., \& Moon, J. (2015). How do firms comply with international sustainability standards? Processes and consequences of adopting the Global Reporting Initiative. Journal of Business Ethics, 131(2), 469- 
486. [https://doi.org/10.1007/s10551-014-2278-5

Walsh, J. (2005). Taking stock of stakeholder management. Academy of Management Review, 30(2), 426-452. https: //doi.org/10.5465/amr.2005.16387898

Wang, Y.J., Zhang, H.L., \& Song, M. (2020). Pure or ambidextrous strategy? A study of responsive and proactive market orientations in industrial firms. Journal of Business \& Industrial Marketing. https://doi.org/10.1108/ JBIM-04-2019-0152 (in press).

Wright, R.T., Campbell, D.E., Thatcher, J.B., \& Robert, N. (2012). Operationalizing multidimensional constructs in structural equation modeling: Recommendations for IS research. Communications of the Association for Information Systems, 30, 367-412.

Yu, H.-C., Kuo, L., \& Kao, M.-F. (2017). The relationship between CSR disclosure and competitive advantage. Sustainability Accounting, Management and Policy Journal, 8(5), 547-570. https://doi.org/10.1108/ SAMPJ-11-2016-0086

Zbuchea, A., \& Pînzaru, F. (2017). Tailoring CSR Strategy to Company Size?. Management Dynamics in the Knowledge Economy, 5(3), 415-437. https://doi.org/10.25019/ MDKE/5.3.06

Zehir, C., Köle, M., \& Yldz, H. (2015). The mediating role of innovation capability on market orientation and export performance: an implementation on SMEs in Turkey. Procedia-Social and Behavioral Sciences, 207, 700708. https://doi.org/10.1016/j.sbspro.2015.10.141 
Appendix 1. Items measuring model constructs

\begin{tabular}{|c|}
\hline CSR measurement scale \\
\hline $\begin{array}{c}\text { CSR information } \\
\text { Based on Gallardo-Vázquez and Sánchez-Hernández (2014b) }\end{array}$ \\
\hline $\begin{array}{l}\text { I1: We are well informed about business initiatives related to SR. } \\
\text { I2 } 2^{\mathrm{a}} \text { : If possible, we always go to meetings on sustainable development and SR. } \\
\text { I3 }{ }^{\mathrm{a}} \text { : We consider the time and resources we spend on SR initiatives and their disclosure vital to our success. } \\
\mathrm{I} 4^{\mathrm{a}} \text { : We have implemented specific initiatives to raise awareness, educate, and inform employees on SR principles and actions. }\end{array}$ \\
\hline $\begin{array}{c}\text { Social dimension } \\
\text { Based on Gallardo-Vázquez and Sánchez-Hernández (2014a) }\end{array}$ \\
\hline
\end{tabular}

SD1: We seek to employ more people at risk of social exclusion.

SD2: We value disabled peoples contributions to the business world.

$\mathrm{SD}^{\mathrm{a}}$ : We are aware of employees quality of life.

SD4: We pay wages above the industry average.

SD5: Employees compensation is related to their skills and results.

SD6 $^{\text {a }}$ : We maintain standards of health and safety beyond the legal minimum.

$\mathrm{SD}^{\mathrm{a}}$ : We are committed to job creation (e.g., fellowships and the generation of job opportunities within the firm).

SD8 $8^{\mathrm{a}}$ : We seek to promote our employees training and development.

SD9: We have human resource policies in place that facilitate a balance between employees professional and personal lives.

SD10: Employees initiatives are extensively taken into account in management decisions.

SD11: Equal opportunities exist for all employees.

SD12: We participate in social projects that benefit the surrounding community.

SD13: We encourage employees to participate in volunteer activities or in collaborative projects with non-governmental organizations.

SD14 $4^{\mathrm{a}}$ : We have dynamic mechanisms in place to encourage dialogues with employees.

SD15: Our company is aware of the importance of having employee pension plans.

Economic dimension

Based on Gallardo-Vázquez and Sánchez-Hernández (2014a)

ED1 ${ }^{\text {a }}$ : We take particular care to offer only high-quality products and/or services to our customers.

$\mathrm{ED} 2^{\mathrm{a}}$ : Our products and/or services comply with national and international quality standards.

ED3: We distinguish ourselves from competitors by maintaining the best price levels in relation to the quality offered.

ED4: The guarantee offered with our products and/or services is broader than the market average.

ED5 $5^{\mathrm{a}}$ : We provide our customers with accurate, complete information about our products and/or services.

ED6 $^{\mathrm{a}}$ : Respect for consumer rights is a management priority.

ED7 ${ }^{\mathrm{a}}$ : We strive to enhance stable relationships that include collaboration with and mutual benefits for our suppliers.

ED8 ${ }^{\mathrm{a}}$ : We understand the importance of incorporating responsible purchasing practices (i.e., we prefer responsible suppliers).

ED9: We foster business relationships with companies in this region.

$\mathrm{ED} 10^{\mathrm{a}}$ : We have effective procedures for handling complaints.

ED11: Our economic management deserves to receive regional or national public support.

Environmental dimension

Based on Gallardo-Vázquez and Sánchez-Hernández (2014a)

AD1: We have been able to minimize our environmental impacts.

$\mathrm{AD}^{\mathrm{a}}$ : We use consumables, goods-in-process, and/or processed goods with a low environmental impact.

$\mathrm{AD}^{\mathrm{a}}$ : We take energy savings into account when seeking to improve our level of energy efficiency.

$\mathrm{AD} 4^{\mathrm{a}}$ : We attach high value to the introduction of alternative sources of energy.

$\mathrm{AD}^{\mathrm{a}}$ : We participate in activities related to the protection and enhancement of our natural environment.

$\mathrm{AD}^{\mathrm{a}}$ : We are aware of investment plannings importance as a way to reduce firms environmental impacts.

$\mathrm{AD}^{\mathrm{a}}$ : We are in favor of reductions in gas emissions and waste production, including recycling materials.

$\mathrm{AD}^{\mathrm{a}}$ : We have a positive predisposition to the use, purchase, or production of environmentally friendly goods.

$\mathrm{AD} 9^{\mathrm{a}}$ : We value the use of recyclable containers and packaging.

$$
\begin{gathered}
\text { CSR diffusion } \\
\text { Based on Gallardo-Vázquez and Sánchez-Hernández (2014b) }
\end{gathered}
$$

D1 ${ }^{\mathrm{a}}$ : SR-related values are present in our firms vision and strategies.

$\mathrm{D} 2^{\mathrm{a}}$ : We are active members of organizations, businesses, and professional association or discussion forums that promote the implementation of SR.

$\mathrm{D}^{\mathrm{a}}$ : Our company has developed collaborative projects with other organizations to promote SR.

D4 $4^{\mathrm{a}}$ : Our firm discloses information about our activities that goes beyond purely business objectives and benefits both the company and society at large.

D5: We are aware of the relative convenience of informing the public about our socially responsible initiatives via all the instruments available (e.g., sustainability reports, codes of conduct, internal reports, and websites).

Note: SR = social responsibility; ${ }^{\text {a }}$ indicators that were validated in the model

Source: Adapted from Gallardo-Vázquez and Sánchez-Hernández (2014a, 2014b) 